\title{
Memórias e projetos em um lugar de estigmas e ressentimentos: uma reflexão etnográfica do lugar Varjão/Rangel no urbano contemporâneo da cidade de João Pessoa - Paraíba \\ Memories and projects in a place of stigma and resentment: an ethnographic reflection of the place Varjão/Rangel in the contemporary urban of the city of João Pessoa - Paraíba
}

\author{
Raoni Borges Barbosa ${ }^{1}$
}

\begin{abstract}
Resumo: Este artigo apresenta uma reflexão etnográfica sobre a cultura emotiva e os códigos de moralidade do lugar Varjão/Rangel, o bairro oficialmente Varjão e oficiosamente Rangel, no urbano contemporâneo da cidade de João Pessoa, Paraíba. A análise se organiza enquanto narrativa assentada em categorias êmicas de moradores do bairro do Varjão/Rangel, tido como um lugar de medos, estigma e pobreza tanto pela cidade quanto pelos próprios moradores do bairro. A classificação moral estigmatizante dos moradores como maleducados, violentos, perigosos e sujos, impacta no Varjão/Rangel de maneira a configurá-lo como lugar liminar, em que disputas morais entre pessoas de bem, engraçadinhos (crianças, adolescentes e jovens envolvidos na pequena violência e em ações criminosas de baixa periculosidade) e pequenos bandidos não se resolvem na forma de estratificações unívocas entre estabelecidos e outsiders. Estas disputas morais cotidianas são vividas no jogo de desculpas e acusações, fofocas e intrigas, amor e ódio, entre os moradores que se apontam mutuamente como sendo pessoas de bem, e, portanto, pertencentes ao Rangel, e supostos personagens moralmente desqualificados, apontados como personagens problemáticos ligados ao Varjão.
\end{abstract}

Palavras-chave: cultura emotiva e códigos de moralidade, disputas morais, estigmas e ressentimentos.

\begin{abstract}
This article presents an ethnographic reflection on the emotional culture and morality codes of Varjão/ Rangel, the neighborhood officially Varjão and not officially Rangel, in the contemporary urban of the city of João Pessoa, Paraíba. The analysis is organized as a narrative based on the emic categories of residents of the neighborhood of Varjão/Rangel, considered as a place of fears, stigma and poverty both by the city and by the residents of the neighborhood. The stigmatizing moral classification of villagers as rude, violent, dangerous and dirty, impacts on Varjão/Rangel in order to set it up as a liminal place, in which moral disputes between good people, funny ones (children, adolescents and young people involved in small violence and criminal acts of low danger) and
\end{abstract}

\footnotetext{
${ }^{1}$ Pesquisador do Grupo de Pesquisa em Antropologia e Sociologia das Emoções da Universidade Federal da Paraíba - GREM/UFPB e doutorando do Programa de Pós-Graduação em Antropologia da Universidade Federal de Pernambuco - PPGA/UFPE. E-Mail: raoniborgesb@gmail.com.
} 
small bandits are not solved in the form of univocal stratifications between established and outsiders. These daily moral disputes are experienced in the game of excuses and accusations, gossip and intrigues, love and hatred, among the residents who point each other out as good people, and therefore belonging to Rangel, and supposedly morally disqualified personal, problematic characters linked to Varjão.

Keywords: emotional culture and codes of morality, moral disputes, stigmas and resentments.

\section{Introdução}

Este artigo apresenta uma reflexão etnográfica sobre a cultura emotiva ${ }^{2}$ e os códigos de moralidade do lugar Varjão/Rangel, o bairro oficialmente Varjão e oficiosamente Rangel, no urbano contemporâneo da cidade de João Pessoa, Paraíba. Trata, assim, do fenômeno da desigualdade, material e simbólica, no urbano contemporâneo brasileiro a partir da análise de entrevistas e conversas informais com o morador do bairro, assim como da apreciação crítica de documentos históricos e geográficos sobre a evolução urbana e dos costumes sociais do bairro e suas comunidades no interior da cidade. A análise se organiza enquanto narrativa assentada em categorias êmicas de moradores do bairro do Varjão/Rangel, tido como um lugar de medos, estigma e pobreza tanto pela cidade de João Pessoa quanto pelos próprios moradores do bairro.

Esta classificação moral estigmatizante dos moradores como mal-educados, violentos, perigosos e sujos, impacta no Varjão/Rangel de maneira a configurá-lo como lugar, - uma territorialidade intensamente perpassada por vetores comunicacionais e interacionias (TRAJANO, 2012), - liminar, em que disputas morais entre pessoas de bem, engraçadinhos (crianças, adolescentes e jovens envolvidos na pequena violência e em ações criminosas de baixa periculosidade) e pequenos bandidos não se resolvem na forma de estratificações unívocas entre estabelecidos e outsiders, mas permanece no jogo de desculpas e acusações, fofocas e intrigas (KOURY \& BARBOSA, 2016), amor

\footnotetext{
${ }^{2} \mathrm{~A}$ cultura emotiva significa um repertório específico de conceitos simbólicos, e comportamentais sendo operado por atores e agentes sociais em interação. Nesta matriz axiológica em constante rearranjo, a interação assume contornos estáveis e as emoções se sucedem como produtos relacionais no jogo indivíduosociedade-cultura. A cultura emotiva de uma sociabilidade específica se configura enquanto possibilidades de práticas e condutas comportamentais e comunicacionais construídas mediante a solução dos problemas de autoridade, de distribuição desigual de bens simbólicos e materiais e, por fim, de divisão do trabalho (MOORE, 1987), revelando a compreensão nativa das concepções de pessoa e de moralidade, de estrutura social e de relações de poder de um grupo social concreto (REZENDE; COELHO, 2010).
} 
e ódio, entre moradores que se apontam mutuamente como sendo pessoas de bem, e, portanto, pertencentes ao Rangel, e personagens moralmente desqualificados - apontados como personagens problemáticos ligados ao Varjão. O Varjão/Rangel, as faces oficial e oficiosa de um mesmo bairro, portanto, aparecem não somente como objeto de conhecimento, mas, e principalmente, como um lugar de reconhecimento recíproco do morador no bairro (MAYOL, 2008).

Nesse sentido, o bairro do Varjão/Rangel é apresentado como contexto interacional denso no interior do processo de evolução urbana da cidade de João Pessoa. A relação histórica e sistêmica entre bairro e cidade enquanto lugares que se incluem geográfica e administrativamente e que se excluem moral e emocionalmente, com efeito, pode ser percebida nos modos de ação e de realidade dos moradores do bairro, cujas personalidades individuais e associações coletivas se veem obrigadas a processar os estigmas da cidade em relação ao lugar Varjão/Rangel no exercício cotidiano de definição da situação e de formação de suas formas sociais de identificação pública.

\section{Cidade e bairro, bairro e cidade: a dialética da pertença envergonhada ${ }^{3}$}

A cidade centenária de João Pessoa, capital do Estado da Paraíba, experimentou uma acelerada expansão demográfica a partir dos anos de 1930, potencializada a partir dos anos de 1970, vindo recentemente a tornar-se a oitava mais populosa cidade da região Nordeste do país e a vigésima terceira do Brasil. A cidade de João Pessoa

\footnotetext{
${ }^{3} \mathrm{~A}$ noção de vergonha é entendida em um contexto de economia das pulsões (ELIAS, 1993, 1994 e 2011) como forma de disciplinamento das interações sociais, onde pessoa e grupo se estruturam em processos de interdependência, que geram uma cultura emotiva baseada em um equilíbrio de tensões. Trata-se, portanto, de como o ator e agente social, no espaço interacional, se situa no âmbito de uma hierarquia dada, de uma rede complexa de papéis, funções e deveres sociais, perante os quais age e reage de forma autocontrolada, disciplinada e reflexiva. O indivíduo relacional, enfim, teme ultrapassar fronteiras sociais e ser alvo de sanções e controles, bem como reconhece e traça estratégias de poder, de controle e unificação de condutas sociais (SCHEFF, 2011). A não observância das fronteiras sociais pode gerar a quebra de contratos implícitos e da confiança depositada no indivíduo, o qual pode vir a ser alvo de sanções negativas. A vergonha é uma emoção eminentemente social, isto é, só ocorre no âmbito do processo de socialização do indivíduo, de modo que é parte integrante do contexto de interação e dos envolvimentos resultantes entre os atores e agentes sociais em cena (GOFFMAN, 2010 e 2012). A forma como uma cultura emotiva constrói o sentimento de vergonha, assim, aponta, por sua vez, para os medos que ali moldam os projetos e trajetórias individuais e coletivos, haja vista que medo e vergonha se condicionam reciprocamente. A vergonha, por exemplo, pode ser entendida como medo de perder a face, ou como uma angústia perante medos que o indivíduo não vê, no momento situacional, capaz de superar. Os medos, uma vez compreendidos para além de uma perspectiva meramente instintiva (sóciopsíquicobiológica) constituem uma prática social no espaço das interações vividas e experimentadas em uma situação determinada.
} 
conta atualmente com um pouco mais de 800 mil habitantes, segundo dados estatísticos de órgãos governamentais ${ }^{4}$, dos quais uma fração considerável é originária do interior paraibano e mesmo de outras capitais brasileiras.

Este processo de crescimento populacional ao longo do século passado foi acompanhando por surtos de urbanização, higienização e embelezamento dos espaços da cidade que "caminhava" progressivamente para o litoral; assim como por intensos empreendimentos e cruzadas morais (GUSFIELD, 1986) de disciplinamento da pobreza urbana (KOURY, 1986), reiteradamente confinada às margens dos bairros nobres e em constante processo de realocação. O deslocamento das populações mais pobres e vulneráveis pela malha urbana em construção ocorria conforme os projetos urbanísticos adequavam-se aos ímpetos modernizantes de políticos e planejadores urbanos, às especulações imobiliárias das forças de Mercado e ao gosto das classes médias e altas de migrarem do centro da cidade, - seu sítio histórico originário, - para a orla marítima, até então ocupada por comunidades de pescadores.

A cidade de João Pessoa, assim, aparece atualmente como um complexo de sociabilidades urbanas caracterizadas por uma cultura do medo (KOURY, 2008), da banalização da violência e da evitação do outro, - tido como estranho, - tensionadas sempre por um processo amplo e inconcluso de modernização conservadora. Modernidade esta sentida ambiguamente como desejo de individualidade e como ameaça às tradições e conformações autoritárias e excludentes do espaço urbano, gerando, assim, sentimentos de amor e ódio à cidade e exigindo do seu morador comum um exercício diário de uma nova sensibilidade, pautada na privatização das emoções, no individualismo, na melancolia e no medo do outro relacional e das incertezas do futuro.

Como resultado deste modelo de modernização conservadora do urbano ${ }^{5}$, posto em prática nos principais centros urbanos do país à época, - como Rio de Janeiro e Recife, - e seguido à risca pelos empreendedores morais ${ }^{6}$ (BECKER, 2008) locais, a

\footnotetext{
${ }^{4}$ Ver notícia: http://g1.globo.com/pb/paraiba/noticia/2016/08/joao-pessoa-supera-marca-de-800-milhabitantes-diz-estimava-do-ibge.html.

${ }^{5}$ A modernização conservadora (DOMINGUES, 2002; MOORE, 1966) significa, em linhas gerais, a imposição, - por parte da burguesia urbana emergente e da velha oligarquia rural politicamente aliançados, - de uma dinâmica de transformações profundas no âmbito das relações entre sociedade, cultura e indivíduo, de modo a modernizar economicamente as potencialidades de uma economia nacional, sem, contudo, permitir uma contrapartida política e social de modernização.

${ }^{6} \mathrm{O}$ conceito de empreendedores morais aponta para a ação pública de atores e agentes sociais des-
} 
cidade de João Pessoa foi paulatinamente conformando-se como uma malha urbana bastante periferizada e cuja cultura emotiva e códigos de moralidade foram fortemente influenciados por esta relação dialética entre bairro e cidade, cidade e bairro, sempre exercitada, pelos bairros populares, como sentimento de pertença envergonhada. Por modelo de urbanização periferizada se entende uma disposição de cidade em que o distanciamento entre a elite política e econômica local e o homem comum pobre se expressa geograficamente de forma bastante evidente: os bairros nobres e os bairros pobres desenham, nesse modelo classicista e autoritário de administração do urbano, não somente manchas territoriais facilmente identificáveis e devidamente separadas fisicamente, como também configuram lugares e regiões morais (PARK, 1925) de memórias, projetos, culturas emotivas, códigos de moralidades, conformações demográficas e econômicas bastante específicas.

Esta segregação de espaços para os ricos e bem sucedidos moradores urbanos e para o restante da população se desdobra cultural e simbolicamente na hierarquização moral dos lugares urbanos: lugares nobres e valorizados e lugares periféricos, de pobreza, violência e sujeira (BARBOSA, 2015). Os bairros nobres e os bairros pobres, nesse contexto de cultura do medo e da violência difusa, definem-se reciprocamente, enquanto lugar na cidade, a partir de um jogo moral, deveras estigmatizante e ressentido, de busca por afirmação e integração moral e econômica no urbano pessoense na medida em que desfiguram as formas coletivas de identificação do outro relacional coletivo.

O Mapa 1 mostra a área territorial, em azul, ocupada pelos bairros nobres da cidade, situados na orla, e os demais bairros, classificados, em geral, como bairros populares, ainda que escalonados de acordo com uma hierarquização territorial moralizante que os diferencia segundo supostos índices de status, prestígio e violência como mais ou menos bons de se morar e como frequentados por pessoas mais ou menos perigosas. Em preto vê-se o contorno do bairro do Varjão/Rangel, um enclave entre a Mata do Buraquinho, em verde, e o bairro planejado como loteamento residencial do Cristo Redentor que o cerca.

tacados no espaço público, e também político, de uma sociabilidade dada. Os empreendedores morais, nesse sentido, atuam como articuladores de agendas sociais de intervenção pública e de transformação social, ou como fazedores de novas regras morais ou como figuras e personagens ritualmente influentes na definição das situações e dos problemas sociais de um contexto interacional e societal específico. 


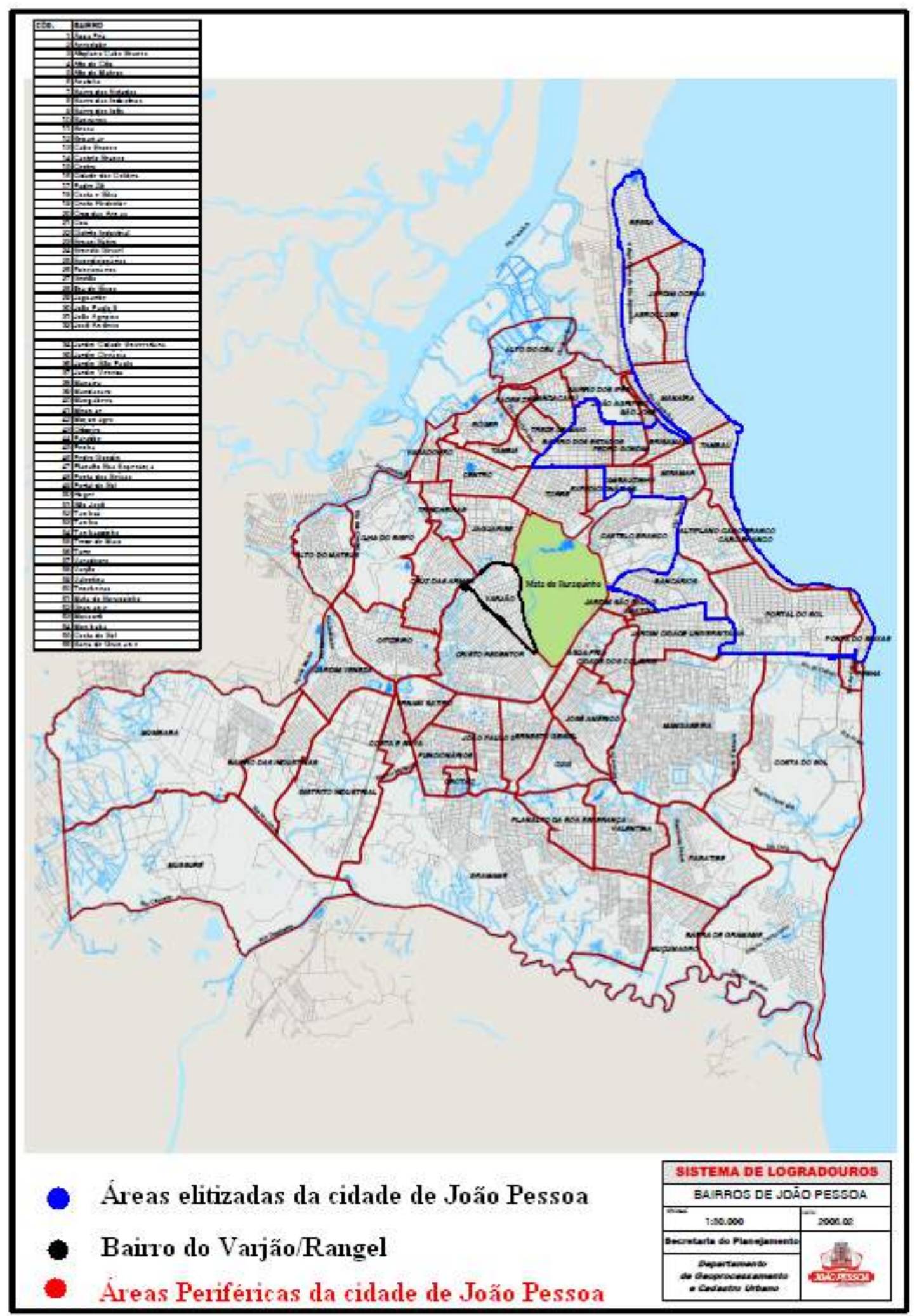

Mapa 1. Mapa de João Pessoa, mostrando as áreas elitizadas e áreas periféricas na configuração atual da cidade (Organizado pelo pesquisador a partir do Mapa da Secretaria de Planejamento da Prefeitura da cidade de João Pessoa). 
A pobreza urbana da cidade de João Pessoa, com e feito, vê-se a si mesmo, em muitos sentidos, a partir do olhar envergonhado e moralizante do empreendedor moral que the qualifica como desvalor, isto é, como contexto interacional inverso ao da fachada que a cidade, na voz de seus atores e agentes sociais destacados, busca performatizar para si mesma como moderna. Os bairros nobres de João Pessoa são representados discursivamente para o público (GUSFIELD, 1986) da cidade como uma fachada urbanisticamente disciplinada e embelezada e, na medida das possibilidades de segregação espaço-temporal das interações, livre dos elementos poluentes e impuros (DOUGLAS, 1991) carreados pelos pobres urbanos.

A pobreza urbana, nesse contexto de interações, está sujeita a um ritual cotidiano de envergonhamento e estigma que se apresenta ora de maneira sutil e velada, ou mesmo de forma escandalosa e jocosa, nos olhares dos pobres urbanos em relação a si mesmo; ora nas narrativas midiáticas, policialescas e de administração das tensões cotidianas no urbano dos empreendedores morais da cidade. Empreendedores morais estes sempre preocupados com a própria segurança e proteção em relação às classes perigosas (MATTOS, 2009) que habitam as periferias.

Esta nova estrutura urbana atua, ainda hoje, no sentido de forçar uma releitura dos moradores sobre suas condições de existência e convivência enquanto lócus de intensa pessoalidade a ser integrado no discurso modernizante da cidade. Este estado latente de tensão irrompeu gradativamente como um sentimento de pertença bastante controverso por parte do morador em relação ao bairro, a um só tempo Varjão e Rangel.

Os bairros pobres, nesta lógica de desfiguração moral (GOFFMAN, 2010 e 2012) por parte dos bairros nobres, são classificados como elementos estranhos, sujos e perigosos em uma cidade ainda em amplo processo de fragmentação e destruição de seus códigos tradicionais de pertença e de reconhecimento. O bairro do Varjão/Rangel, por extensão, aparece como sociabilidades urbanas periféricas e pobres, ainda por modernizar e civilizar, e que suscitam medo e evitação à cidade oficial, mas como lugar de confiança e de confiabilidade, de pertença, em que a vida cotidiana do morador era, - e ainda em certa medida busca ser, - organizada em redes homofílicas e de parentesco extenso, de compadrio, de amizade, de reconhecimento, de lealdade e de solidariedade 
em relação ao outro, vizinho e próximo.

As sociabilidades urbanas no Varjão/Rangel, contudo, aparecem continuamente tensionadas por disputas morais em torno do pertencer à cidade oficial e por medos corriqueiros, reais e imaginários, gerados, por exemplo, no confronto com o outro de fora do bairro. Este outro relacional de fora do bairro desconhece e confunde os idiomas morais e emocionais em torno das nominações, lugares e memórias relacionados ao Varjão e ao Rangel. Nesse sentido, o bairro do Varjão/Rangel reproduz, em seus contextos interacionais, a dinâmica de envergonhamento e de desfiguração moral que a cidade oficial de João Pessoa, na voz publicizada de seus empreendedores morais, projeta para os bairros populares e periféricos, tidos não mais como elementos pitorescos e folclóricos de um atraso social romantizado como exótico (BARRETO, 1996), mas como áreas classificadas como problemáticas para e pelo poder público em razão dos focos ali concentrados de violência urbana e de moralidade degrada e ameaçadora para o cidadão de bem.

Esta imagem da cidade sobre o Varjão/Rangel é associada oportuna e convenientemente pelo morador do bairro a uma moralidade, toponímia e conjunto de memórias e histórias do Varjão, signo de vergonha cotidiana e de acusação do outro próximo que se quer evitar cotidianamente como não sendo o si mesmo, mas um passado superado de pobreza, de incivilidade e de moralidade de baixo padrão. O Rangel, com efeito, por oposição e complementação, remete a emoções, lugares e memórias associados às pessoas de bem do bairro e suas respectivas narrativas de integração moral, econômica e política à cidade oficial de João Pessoa; mas também aparece nos discursos e ações do morador do bairro como argumento de justificação de si e de acusação e exclusão do outro que se quer inferiorizar, humilhar e desfigurar moralmente.

O bairro do Varjão/Rangel, nesse sentido, é enquadrado como produto histórico das ofensivas civilizadoras e modernizantes das décadas de 1960 e de 1970, que buscaram expandir a malha urbana da cidade de João Pessoa para o sul, abrindo espaço para a acomodação de populações de baixa e média renda nos novos loteamentos populares financiados pelo Estado autoritário militar, nas proximidades de grandes empreendimentos urbanos, como a Universidade Federal da Paraíba, a BR 230, o Estádio de Futebol Almeidão, entre outros. O projeto autoritário de transformação acelerada das antigas 
comunidades da grande várzea do Rio Jaguaribe resultou em um bairro, pobre e estigmatizado, em cujo interior ainda permanecem suas comunidades originárias, agora no formato, estigmatizado e ressentido, de aglomerados subnormais ${ }^{7}$.

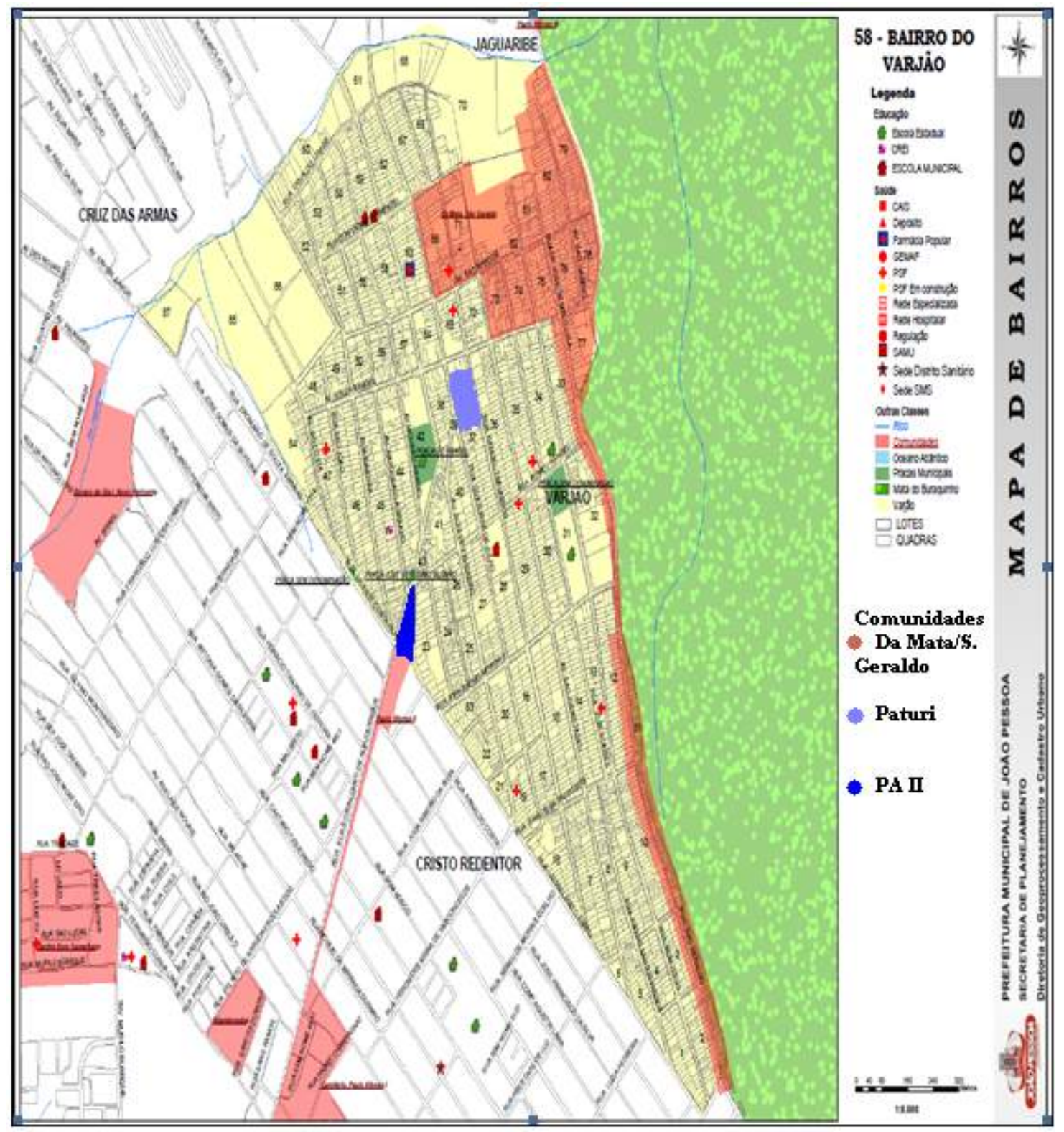

Mapa 2. Localização de três comunidades no bairro Varjão/Rangel. Mapa modificado pelo autor. (Fonte: Secretaria de Planejamento da Prefeitura da cidade de João Pessoa).

O Mapa 2 mostra a localização das três comunidades ou dos aglomerados subnor-

\footnotetext{
${ }^{7}$ Até o final da década de 1980 o planejamento urbano da cidade de João Pessoa denominava as áreas mais carentes e vulneráveis de aglomerados subnormais. Esta forma de classificação se modificou a partir dos anos de 1990, de modo que passaram a ser denominadas de comunidades. Os dois termos estão sendo utilizados em um mesmo sentido, como sinônimos que remetem a uma segregação espacial extrema dentro da malha urbana dos bairros da cidade e a um lugar de evitação, perigo e sujeira moral.
} 
mais que também compõem a paisagem humana e urbana do Varjão/Rangel. Trata-se, em um dos casos, da Comunidade São Geraldo ou da Comunidade da Mata, que se estende na fronteira leste do Varjão/Rangel no sentido Norte - Sul, ocupando uma área que, em parte, pertence oficialmente à União em razão de estar destinada à preservação ambiental. A Comunidade São Geraldo compreende não somente a Rua São Geraldo, mas um conjunto de ruas na área nordeste do bairro. É um longo e estreito corredor desalinhado, em estrada de barro, apinhado de moradias precárias, bares tipo botecos, algumas poucas igrejas evangélicas improvisadas e ainda um terreiro. Conta com uma população densa, de muitas crianças, adolescentes e jovens, sempre em intensa atividade.

A comunidade Paturi, por sua vez, fica localizada na parte central do Varjão/Rangel e ocupa um pouco mais do que a área de dois quarteirões, de modo que se organiza na forma de um beco bastante sinuoso, - de habitações ainda extremamente precárias geminadas de forma improvisada, - que leva da Rua Quartoze de Julho à Rua Rangel Travassos. Assim como a Comunidade São Geraldo, a Comunidade Paturi se caracteriza por uma pessoalidade ainda mais intensa do que a que se pode observar cotidianamente nas demais áreas do Varjão/Rangel, sendo conhecida como umas das áreas mais vulneráveis e estigmatizadas do bairro. Ali convive em regime de forte copresença uma dúzia de família, aproximadamente. É impossível atravessar de carro a Comunidade Paturi, haja vista ser um corredor estreito e perpassado por um canal de esgotamento sanitário.

A terceira e última comunidade ou aglomerado subnormal que se apresenta na sociabilidade do bairro é conhecida por Paulo Afonso II e se situa na fronteira oeste, atingindo a Rua Leonel Pinto de Abreu, onde o Varjão/Rangel se encontra com o bairro do Cristo Redentor e por ele se expande. A área desta comunidade é bastante reduzida, bem como a população que abriga. O impacto desta comunidade no imaginário dos moradores do bairro parece ser bastante acentuado, haja vista que a nominação Paulo Afonso também se aplica a outro aglomerado subnormal localizado ao norte do Varjão/Rangel, oficialmente conhecido como Comunidade Paulo Afonso III, mas já localizado para além da fronteira norte do Varjão/Rangel. 
A cidade de João Pessoa, em resumo, traz consigo as marcas deste desenvolvimento assimétrico, característico de uma acomodação do espaço urbano pautada na lógica societária da economia de mercado e da superexploração do homem comum pobre. A cidade desenvolveu-se de forma acelerada nas últimas quatro décadas, transformando-se em um espaço societal urbano de relações cada vez mais individualizadas e impessoais (KOURY, 2007). A expansão do capitalismo no Brasil, dinamizada a partir da década de 1960 do século passado, levou o plano de modernização forçada ao paroxismo, como se verifica na extensa área periférica da cidade de João Pessoa, resultante, entre outros fatores, da migração no sentido campo-cidade de levas de trabaIhadores expulsos de suas terras, o que massificou a presença de favelas nas cidades brasileiras.

O bairro do Varjão/Rangel se organiza neste contexto de abertura de novas áreas urbanas para o abrigo imediato de populações de baixa renda. A princípio tratava-se de pequenas comunidades tradicionais conhecidas como aglomerados relativamente isolados na grande várzea do Rio Jaguaribe, também relatada como Jaguaribe de baixo. Área de difícil acesso, a população ali abrigada dispunha amplamente da mata atlântica e do rio como recursos econômicos livres. Sob a pressão do processo acelerado de modernização e expansão da cidade, principalmente a partir da década de 1970, estas comunidades se viram constrangidas, amedrontadas, envergonhadas e em constante tensão e conflito com o poder público e pela construção acelerada de conjuntos habitacionais na zona sul da cidade.

O Mapa 3 busca situar os limites geográficos do bairro, oferecendo, assim, uma ideia do processo de conformação urbanística das antigas comunidades da Grande Várzea do Rio Jaguaribe no atual Varjão/Rangel. Observa-se, então, os bairros de Jaguaribe e de Cruz das Armas, ao norte, o bairro do Cristo Redentor a oeste e ao sul, e a Mata do Buraquinho, a leste.

Embora se tenha notícia da presença de moradores desde a década de 1920, somente nos anos de 1980 a ocupação no bairro se adensou, seguindo uma lógica de reestruturação profunda da distribuição espacial e populacional na capital paraibana. O Varjão/Rangel se localiza na zona oeste de João Pessoa e faz parte de uma área alvo 


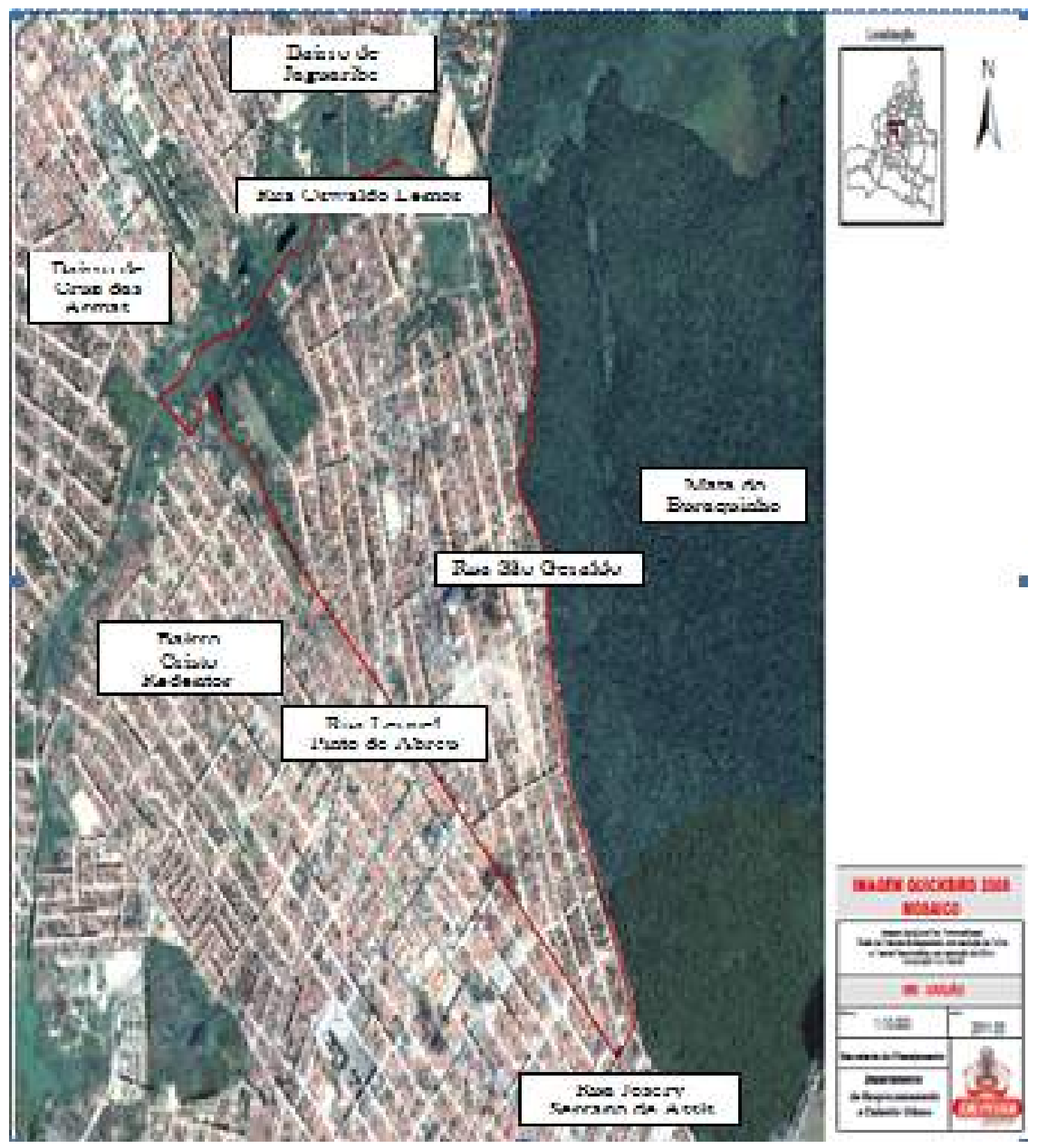

Mapa 3. Bairros e ruas fronteiriças do Varjão/Rangel (Organizado pelo pesquisador a partir do Mapa da Secretaria de Planejamento da Prefeitura da cidade de João Pessoa). 
de um discurso oficial e midiático que o classifica como de uma sociabilidade deveras violenta, perigosa e, em muitos aspectos, ainda por civilizar.

Esta forma da cidade representar o bairro dá azo a justificativas que submetem não só o território em questão a controles sociais vários, como a presença ostensiva de patrulhamento policial e de agentes comunitários de saúde, mas a todo um esforço de isolamento e estigmatização do lugar enquanto elemento intrínseco da pertença de seus moradores. Território e lugar do Varjão/Rangel, assim, passam a ser alvos de uma imagem e discurso por parte de uma cidade que amedronta e envergonha quem ali constrói sua convivência cotidiana.

\section{Memória e projetos: o lugar Varjão/Rangel no discurso estigmatizado e ressentido do morador}

O Varjão/Rangel abriga, em sua maioria, moradores oriundos de cidades interioranas da Paraíba e de outros estados da federação, como do Rio Grande do Norte e de Pernambuco, e sua ocupação, ainda hoje, se processa mediante o apoio oferecido pelas famílias e pela vizinhança articulados em rede. Estas redes migratórias egocentradas ou homofílicas contribuem consideravelmente para o estreitamento dos vínculos de amizade e dádiva, facilmente oscilando entre amor e desamor, entre os vizinhos, amigos, conhecidos e parentes no bairro.

O bairro conta atualmente com 4701 domicílios e uma população estimada de 16.900 habitantes, em sua grande maioria, quase $80 \%$, com renda de até um salário mínimo, de acordo com os dados do último censo do IBGE (2010). Em razão das políticas sociais e habitacionais dos últimos anos o Varjão/Rangel se encontra em movimento acelerado de reestruturação urbana, de modo que novas vilas e novos residenciais verticalizados passam a compor a paisagem urbana de várias ruas do bairro. Percebe-se, contudo, uma curva interessante de investimentos ascendentes em capital econômico do bairro no próprio bairro, de 2012 até fins de 2015, quando a atividade de empresas familiares de construção civil começa a dar claros indícios de desaceleração dos trabalhos e mesmo de falência total dos projetos.

O bairro é composto por trinta e cinco vias, das quais três aparecem como avenidas (Av. Dois de Fevereiro, Av. José Soares, Av. Mourão Rangel), uma delas se 
caracteriza como travessa (Travessa Vicente Costa Filho) e as demais se apresentam como ruas. As vias Av. Mourão Rangel e as Ruas Rangel Travassos, Romeu Rangel e Souza Rangel chamam a atenção pelo patronímico que é colocado pelos moradores do local como razão de ser da nominação oficiosa do bairro. Diversas narrativas concorrem pela explicação nativa do patronímico Rangel para dar nome ao lugar das pessoas de bem e do projeto coletivo de integração moral e econômica do bairro à cidade de João Pessoa: a mais conhecida narra a presença da família Rangel no bairro, que teria sido a proprietária de grande parte do território e que o teria arrendado e vendido paulatinamente aos moradores que chegavam do interior do Estado e buscavam acomodação na região, construindo suas casas de taipa.

Interessante notar, ainda, o quanto a religiosidade e a tradição se manifestam no espaço público e cotidiano da população nos nomes de Ruas em homenagem a figuras sagradas. Este fenômeno se verifica nas seguintes Ruas: Bom Jesus, São Gabriel, São Geraldo, São João, São Judas Tadeu, São Marcos e São Severino. Este conjunto toponímico é ainda, com efeito, reforçado pela presença de três igrejas e uma capela de tradição católica, situadas em pontos destacados de bastante visibilidade na geografia do bairro e que, no entender de alguns moradores mais antigos, apontam para os caminhos originários da colonização da área Varjão desde princípios do século XX.

Em uma conversa informal com uma família que está há três gerações no bairro, o pesquisador pode registrar uma narrativa de colonização da área da grande Várzea do Rio Jaguaribe da perspectiva da chegada da Igreja Católica. Os informantes, aqui chamados de Carlos e Carlinhos, sendo eles respectivamente pai e filho, narraram todo um sentimento de pertença ao Varjão/Rangel, identificado como Rangel e mesmo como Cristo/Rangel, mas jamais como Varjão, - a não ser como situação passada e superada, - a partir de uma trajetória de vivências ligadas à filiação religiosa católica e também de certa proximidade com a família Rangel, que, segundo eles, era a antiga proprietária daquelas terras onde hoje se situa o Varjão/Rangel.

O seu Carlos se apresentou como diácono da igreja católica, explicando, logo em seguida, que já fora responsável pela igreja do Bom Jesus e que, diferentemente de padre, diácono tem a permissão de casar. Em relação à questão da nominação Varjão/Rangel do bairro, ele fez uma longa digressão sobre a história da sua família, intimamente ligada à história do bairro. 
Comentou que a nominação Varjão ser referia à "[...] área da vargem, ali próximo ao rio Jaguaribe, que era um rio grande aonde meu pai ia tomar banho e aonde a minha mãe ia lavar roupa. Ali se plantava muito feijão na vargem, mas se acabou. Hoje, quando eu lembro que meu pai diz isso, a gente pensa que é brincadeira, mas é verdade. Ali era tudo Varjão, quando eu nasci. Não tinha calçamento nenhum por aqui, era tudo mata. Esse terreno mesmo era de 'mata de vara', de onde a gente vinha para tirar mata e fazer cerca ou para fazer as casas que eram todas de taipa. Eu fiz muito isso, quando era menino: pisava o barro com os pés (demonstra a técnica corporal própria para o trabalho de preparar o barro para a construção), fazia uma bola e ia enchendo as paredes, e às vezes colocava uma pedra dentro para diminuir a quantidade de barro. Tinha muito isso no Rangel. Mutirão que se juntava para fazer casa, que era tudo de taipa, que o pessoal fazia com varas tiradas da mata. Na rua do meu pai, era todo mundo trabalhador na construção civil (pedreiro, encanador, eletricista) ou era soldado de polícia. Não tinha carros, no bairro, e todo mundo andava a pé. De manhã, logo cedo, ficava a ladeira cheia de gente indo para a cidade a pé, que você via a ladeira cheia. Aquela praça onde hoje tem a igreja matriz (a igreja São Francisco das Chagas), não tinha, porque ali era um areal, onde se formava muitas pequenas lagoas, porque brotava água do chão, e só depois que taparam e se acabou tudo. A igreja que tinha, a matriz, era a igreja São Francisco de Assis, que era dos Salesianos e depois que eles passaram para os Franciscanos. O Rangel começa ali, e foi crescendo na direção da Rua Souza Rangel, e só bem depois que veio vindo para o lado de cá. Antes, quando começo a ter ônibus, ele parava ali na igreja e voltava, porque aqui não tinha nada, só 'mata de vara'. Começa a crescer mesmo com o loteamento que a família Rangel fez, quando começou a chegar muita gente do interior e só achava lugar aqui. Depois que começa o Cristo e o Almeidão (Estádio de Futebol da cidade), que foi uma obra que ninguém sabe quem fez de tão grande e que ainda hoje não está terminada, e que para assistir aos jogos tinha todo mundo que passar pelo Rangel, que era um corredor para chegar lá, porque não tinha a BR-230 e o caminho era só por aqui mesmo. Aí ia todo mundo do bairro para ver os carros, porque aqui a gente não tinha carros, e via a fila de carros passar. Quem podia, naquela época, comprava cavalo e andava de cavalo, até a brincadeira era de cavalo: "acertar argolinha". Mas quem não tinha andava a pé mesmo, e quando pode, comprou uma bicicleta: até hoje pai, que era pedreiro, anda de bicicleta, que sempre foi o transporte dele, por isso é conhecido como Joca da Bicicleta. Lá, na vargem, era Varjão, mas quando o pessoal começou a vir mesmo, a família Rangel ajudou muita gente a ficar aqui. Maria José Rangel Travassos que herdou essas terras, onde ficava a Fazenda Varjão. Ela era uma pessoa muito querida e popular demais: andava tudo isso aqui a cavalo, falava com as pessoas, ela ia às casas tomar café. E ela também recebia as pessoas: a porta tava sempre aberta e as pessoas que tinham recebido dela a "posse" de um terreno, pagava lá mesmo a quantia anula e já pegava um recibo. Era uma quantia simbólica mesmo, como se fosse hoje $R \$ 10,00$, só para dizer que a gente pagava pelo direito. $E$ quando tinha uma briga de vizinho, porque um queria botar uma cerca e tomava uns metros do outro, vinha ela aqui e media os terrenos e resolvia. Eu sei que a família mora agora ali perto da Padaria $A B C$, no bairro do Jaguaribe. Mas não sei como são os netos dela. Hoje, tudo mudou, e ninguém mais recebe os outros assim, de portas abertas".

Neste ponto, o Carlinhos interrompeu a conversa para informar que a senhora Norma Rangel era a representante da família que mais se apro- 
ximava do bairro, inclusive visitando antigas amizades da Rua da Mata. Mas, acrescentou, tinha ouvido rumores de que ele teria morrido há pouco. Seu Carlos disse não saber confirmar a informação, porque a família Rangel agora estava mais afastada das pessoas do bairro, muito embora muita gente pagasse ainda pela "posse" dos seus terrenos.

A senhora Norma Rangel, de todo modo, explicou seu Carlos, "era só a nora de um dos netos de Maria José Rangel Travassos, a quem os moradores queriam muito. Eu mesmo fui muitas vezes lá pagar a "posse" do terreno. Todo ano eu ia". A presença simbólica da família Rangel, bastante evidente no nome de várias ruas do bairro (Rangel Travassos, Mourão Rangel, Souza Rangel, Romeu Rangel), e de um residencial construído pela família na Rua São Judas Tadeu (Residencial Normal Rangel), rivalizava somente com a presença dos Salesianos e dos Franciscanos, que os substituíram, e marcaram o ethos e a visão de mundo do morador do bairro, tal como se podia, também, verificar no nome das ruas (São Judas Tadeu, Bom Jesus, São Marcos, São Geraldo).

Esta relação umbilical dos moradores do bairro com a família Rangel e com a igreja católica, a primeira na forma de "senhora das terras" e a segunda na forma de "senhora das almas", era o que buscava afirmar o seu Carlos. Carlinhos, neste sentido, colocou o fato de que muitas famílias chegavam do interior, mas que também moravam já naquelas terras alguns índios da tribo Ubirajara, ao que o pai acedeu afirmativamente.

Seu Carlos e Carlinhos eram, respectivamente, a primeira e a segunda geração nascidas e criadas no Rangel, mas originalmente a família tinha se deslocado do brejo paraibano e do litoral norte para a cidade de João Pessoa que crescia e se urbanizava. O pai de seu Carlos, o seu Joca da Bicicleta, era originário da cidade de Caiçara. A família da sua mãe, por outro lado, era originária do município de Forte Velho, hoje anexada ao município de Lucena, bem próximo ao município de Cabedelo, mas a mãe nascera também no Rangel.

Seu Carlos contou que a energia elétrica só chegara para a sua rua, Napoleão Laureano, em 1965. "Foi uma grande festa, porque quando a energia chegou, foi de uma vez: tinha o dia todo. Não sei dizer se chegou no bairro inteiro, porque eu era muito novo e limitado das coisas, só posso dizer sobre a minha rua, que era onde eu brincava sem camisa, descalço, correndo para cima e para baixo. Mas aí só depois de alguns anos que chegou a água. Eu vi a terra sendo cavada para colocar os canos da tubulação. Antes a gente ia a pé e pegava água na cacimba, em frente a igreja São Francisco. Eu ia com a cangalha e pegava dois baldes de água. Fiz isso muito. Mas depois chegou a água encanada. Eu andava por Jaguaribe, pela Torre, naquela época, e ficava encantado com as casas de tijolo e de muro. Aqui as casas eram todas só de taipa e não tinham muro, só cerca de vara. Eu achava o bairro muito feioso. Mas depois chegou o tijolo queimado e as casas começaram a ser feitas de tijolo queimado, porque antes era de barro cru. Aí as casas começaram a ser feitas de tijolo e a ter muros. Depois teve um tempo muito ruim o bairro, quando começaram a trazer coisa ruim para cá. Porque muita coisa ruim que acontece no Cristo, aparece como se fosse no Rangel. Morria alguém lá, mas traziam o corpo para cá e diziam que tinha aparecido no Rangel. Ainda hoje se fala negativamente do bairro, quando na verdade não tem isso. Hoje já melhorou muito, e o bairro agora tem tudo: até a gestão do prefeito Cícero Lucena o bairro crescia na raça do morador, que fazia as coisas ir para a frente. Mas daí em diante o poder público, a prefeitura, botou a mão e não parou mais de crescer". 
Carlinhos contou, em seguida, que a igreja do Bom Jesus, a igreja São Francisco de Assis (primeira igreja matriz do bairro), a igreja Nossa Senhora das Graças e a igreja São Francisco de Chagas formam a paróquia do bairro do Rangel ${ }^{8}$, da qual sua família participa de forma destacada, conhecendo de perto os padres, diáconos e moradores frequentadores das igrejas.

Carlinhos se apresenta como entusiasta do lugar Rangel, que em sua ótica se destaca como uma sociabilidade pulsante de registros culturais: "O bairro é muito rico em aspectos culturais. Não sei se você sabe, mas recentemente Vô Mera foi gravar para a novela Velho Chico. Ela é muito conhecida aqui e participou de umas cenas da novela. $E$ tem também o Urso Batucada, que já ganhou várias vezes o prêmio do carnaval. Ele fica ali na Souza Rangel, na esquina da padaria. E tem também os índios da tribo Ubirajara. Eu também sou índio, mas misturado com negro. O bairro tem muita coisa e sempre tá acontecendo alguma coisa, nas igrejas, nas praças, nas ruas mesmo".

Por outro lado, Carlinhos narra a situação social de exclusão social da maioria das famílias do bairro. Ao contrário de muitos amigos de infância e de adolescência, por exemplo, "que eram mais... que eram menos favorecidos financeiramente", ele frequentou uma "escola particular" que se situa no bairro do Cristo Redentor. Já naquela época alguns amigos, quando perguntados onde moravam, diziam que moravam no Cristo, para não ter que passar pelo constrangimento do preconceito de ser associado à identidade Rangel.

Segundo Carlinhos, sempre existiu uma confusão entre Cristo e Rangel para os moradores da cidade de João Pessoa, mas no Rangel todos sabem que se trata de um único e mesmo bairro, o Cristo/Rangel, só "que o Rangel ficou como o irmão pobre e o Cristo ficou como irmão rico". Conta, neste sentido, que tem comércio, no bairro, que se chama Cristo/Rangel, assim como a academia onde ele praticava Karatê: Academia Cristo/Rangel. Segundo Carlinhos: "O Cristo nasceu do Rangel. Pelo que eu sei, antes só tinha o Rangel, aí, quando começam a fazer o Cristo, algumas famílias mais bem favorecidas vão morar por lá e no Rangel ficam as pessoas mais carentes. Lá você vê umas casas grandes, boas, que o pessoal construiu quando foi para lá".

Carlinhos conta que está cada vez mais difícil encontrar um lugar, ainda que provisório, no bairro: casas para vender ou alugar, quando são encontradas, subiram muito de preço. Muitos dos seus amigos que já casaram ou que já estão em idade de casar, assim como ele, hoje moram em bairros como Paratibe e Colinas do Sul, mas continuam frequentando o Rangel, onde tem suas famílias e amigos.

Ao ser provocado pelo pesquisador sobre um possível processo de verticalização do bairro, Carlinhos responde afirmativamente. "Esse processo de verticalização a gente vê nas famílias mesmo, porque tem muita família de amigo meu fazendo primeiro andar na casa da família, porque os filhos e ninguém querem sair daqui, não. Como eu disse, a gente quer ficar no bairro. Hoje eu vejo muitos prédios sendo feitos no bairro, mas também a verticalização é nas casas, porque a gente acha que é só com prédios".

${ }^{8} \mathrm{O}$ bairro do Rangel, que hoje conta com uma paróquia autônoma, já fez parte da paróquia do bairro do Jaguaribe. Por esta razão, diz Vandinho, muitas vezes é preciso subir a "ladeira do antigo Varjão" para averiguar se alguém que queira crismar-se ou casar-se possui, de fato, um documento que ateste o seu batismo. Na paróquia de Jaguaribe, no igreja do Rosário, se encontra ainda o livro de Tombo com informações sobre a história e a população que mora no Rangel. 
Sobre a nominação Varjão para o lugar também disputado moralmente como Rangel, Carlinhos argumenta que Varjão era o nome da área próxima ao rio Jaguaribe, e isto somente até o tempo em que se começou a lotear o território que hoje compreende o Rangel.

Carlinhos contou ainda que observa de forma esperançosa o futuro do Rangel: a verticalização já em curso do bairro poderá garantir um lugar para ele e para os amigos que tiveram que sair momentaneamente do Rangel; a urbanização e a integração econômica de áreas antes abandonadas do bairro já garante uma maior qualidade de vida à atual geração de jovens do bairro, o que a geração do seu pai não pode experimentar. "Hoje tem linha de ônibus que leva para todo canto. E eu vejo os prédios sendo construídos no bairro todo", disse. E acrescentou: "A gente quer morrer aqui mesmo. Se der, eu quero morar aqui... o problema é que a gente não mora sempre onde quer, mas onde tem o "cacau". Minha noiva também é daqui, mas agora tá no Valentina. Mas eu já to vendo um primeiro andar aqui em casa, porque não quero sair".

Interessante notar, na fala nativa, como o lugar Rangel, ao ser confrontado com o lugar Cristo Redentor, - bairro planejado para a classe média e que constrangeu as comunidades da grande Várzea do Rio Jaguaribe a um formato administrativo de bairro, - aparece como pertença sentimento de pertença envergonhada, de modo que um discurso de evitação de informações sensíveis e de desculpas de si é imediatamente acionado: para o morador de classe média do Rangel, os bairros Cristo Redentor e Rangel são, de fato, um só; ainda mais porque o Cristo teria nascido no Rangel. O lugar Varjão, por sua vez, ou aparece como passado superado ou como área distante do círculo de influência das igrejas que marcaram o processo de colonização do bairro. Varjão, assim, indica um lugar de estranheza e de evitação, bem como um recurso de acusação do outro que contamina o Rangel, lugar de pessoas de bem e que pretende conquistar o reconhecimento moral da cidade de João Pessoa como bairro civilizado.

As fotos abaixo, de 1 a 7 , buscam melhor ilustrar a fala nativa de Carlos e Carlinhos, situando os marcos urbanísticos, e também morais e emocionais, que conformam a narrativa de pertença deles ao Varjão/Rangel. O papel das igrejas como monumentos à conquista espacial do território e de conformação do lugar como social, portanto sagrado (DUKHEIM, 2003), e dos selves dos moradores do bairro como de pessoas moral e emocionalmente dignas, é bastante evidente.

A distribuição longitudinal do Varjão/Rangel, no sentido Norte - Sul, que parece ter orientado a ocupação histórica do território, pode ser hipoteticamente inferida nas várias vias que se organizam como corredores do bairro. De uma extremidade à outra cruzam 


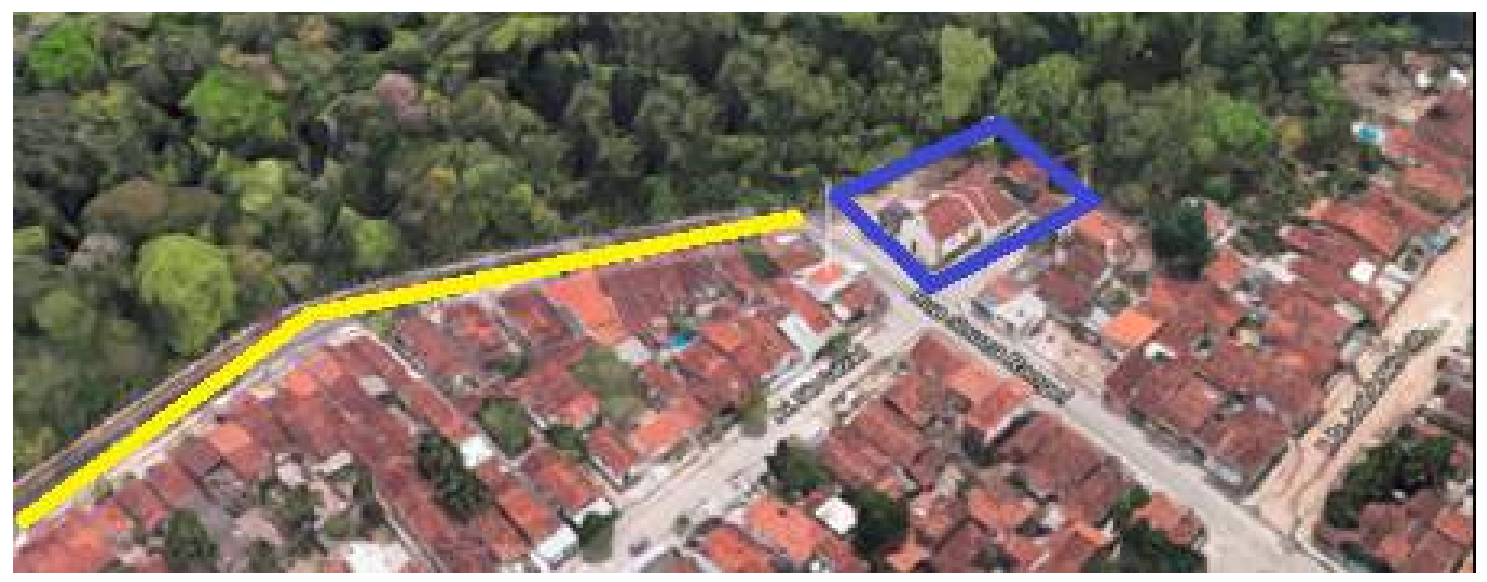

Foto 1. Visão aérea da antiga e mítica Ladeira do Varjão, em amarelo, e destaque, em azul, para a Igreja São Francisco de Assis, primeira igreja matriz do bairro e onde o mesmo teria começado. A Ladeira do Varjão comunicava precariamente, até metade do século XX, o Centro de João Pessoa com as Comunidades da Grande Várzea do Rio Jaguaribe.

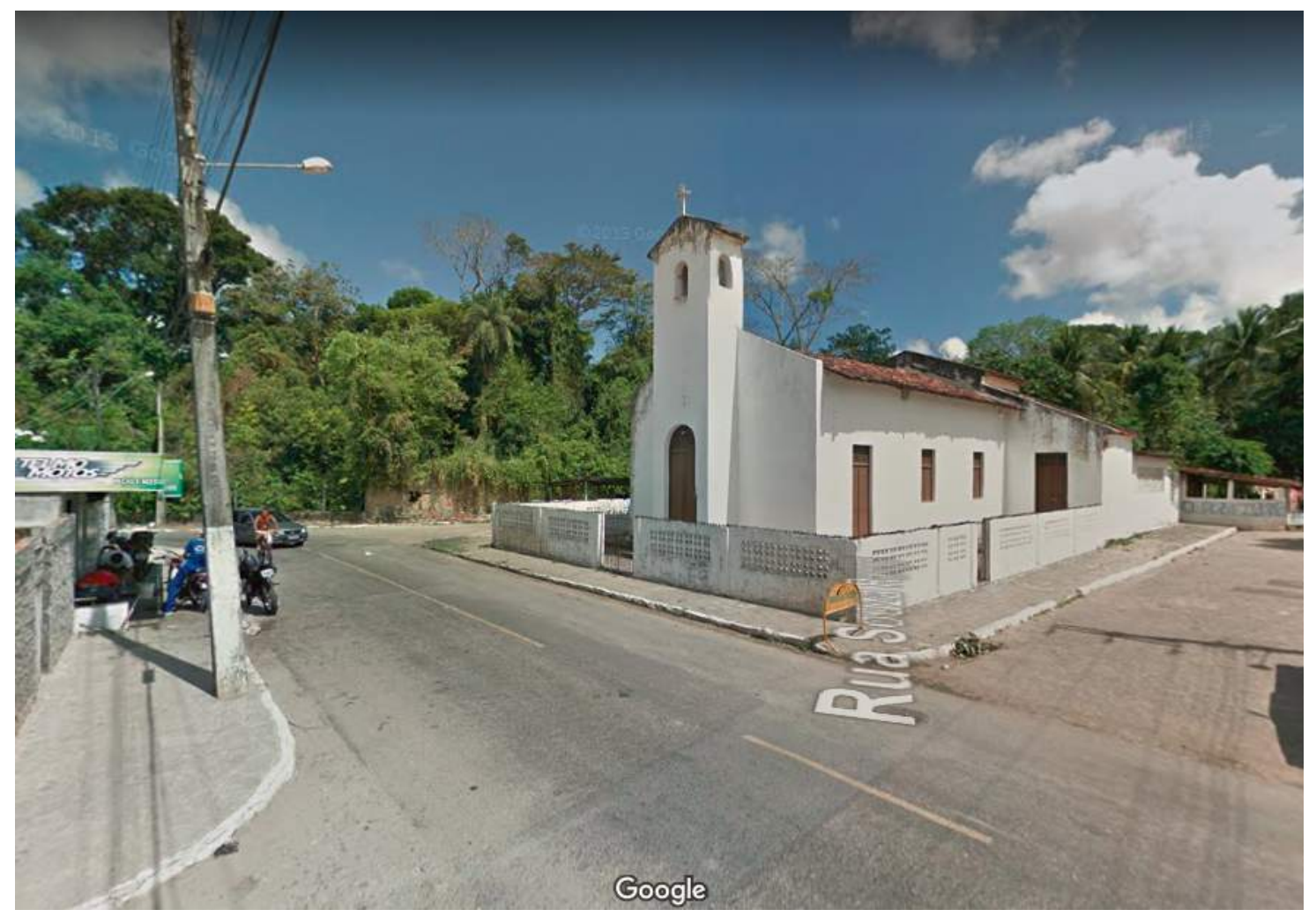

Foto 2. Visão em perspectiva da Igreja São Francisco de Assis, na início da Rua Souza Rangel, onde termina a Ladeira do Varjão, margeando a Mata do Buraquinho. 


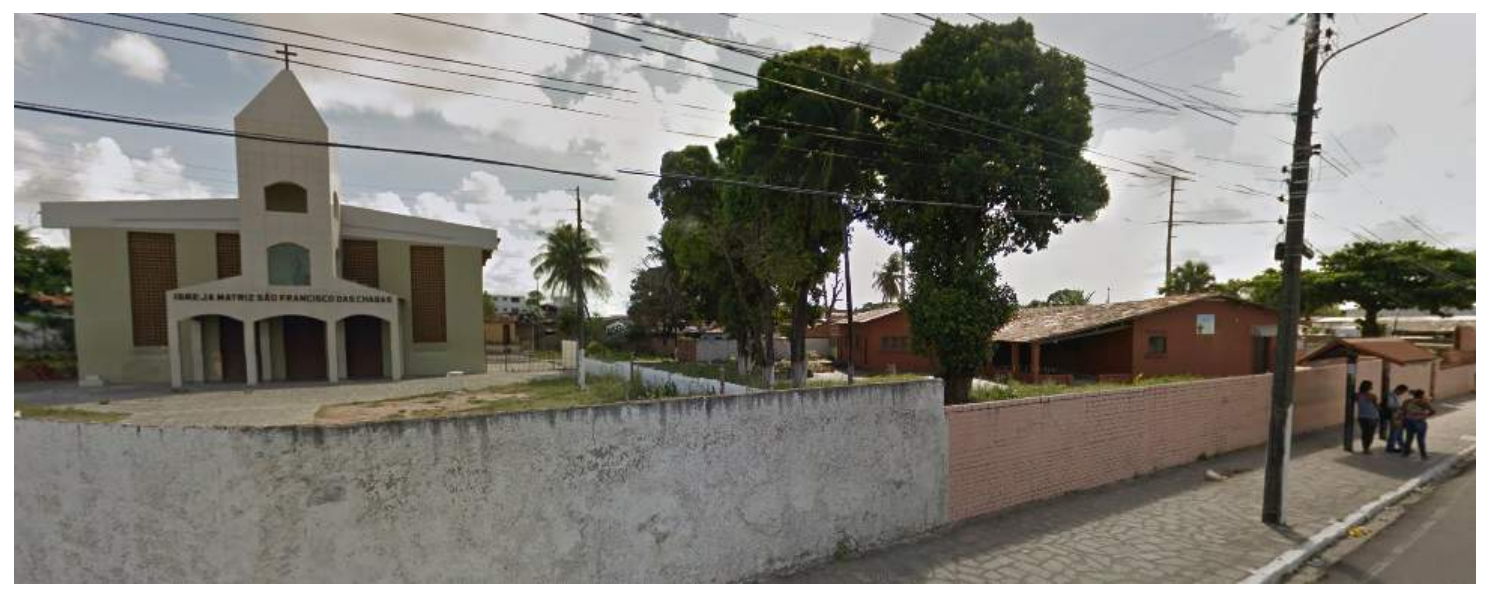

Foto 3. Visão frontal, desde a Rua 02 de Fevereiro, da Igreja São Francisco de Chagas, atual igreja matriz do Varjão/Rangel.

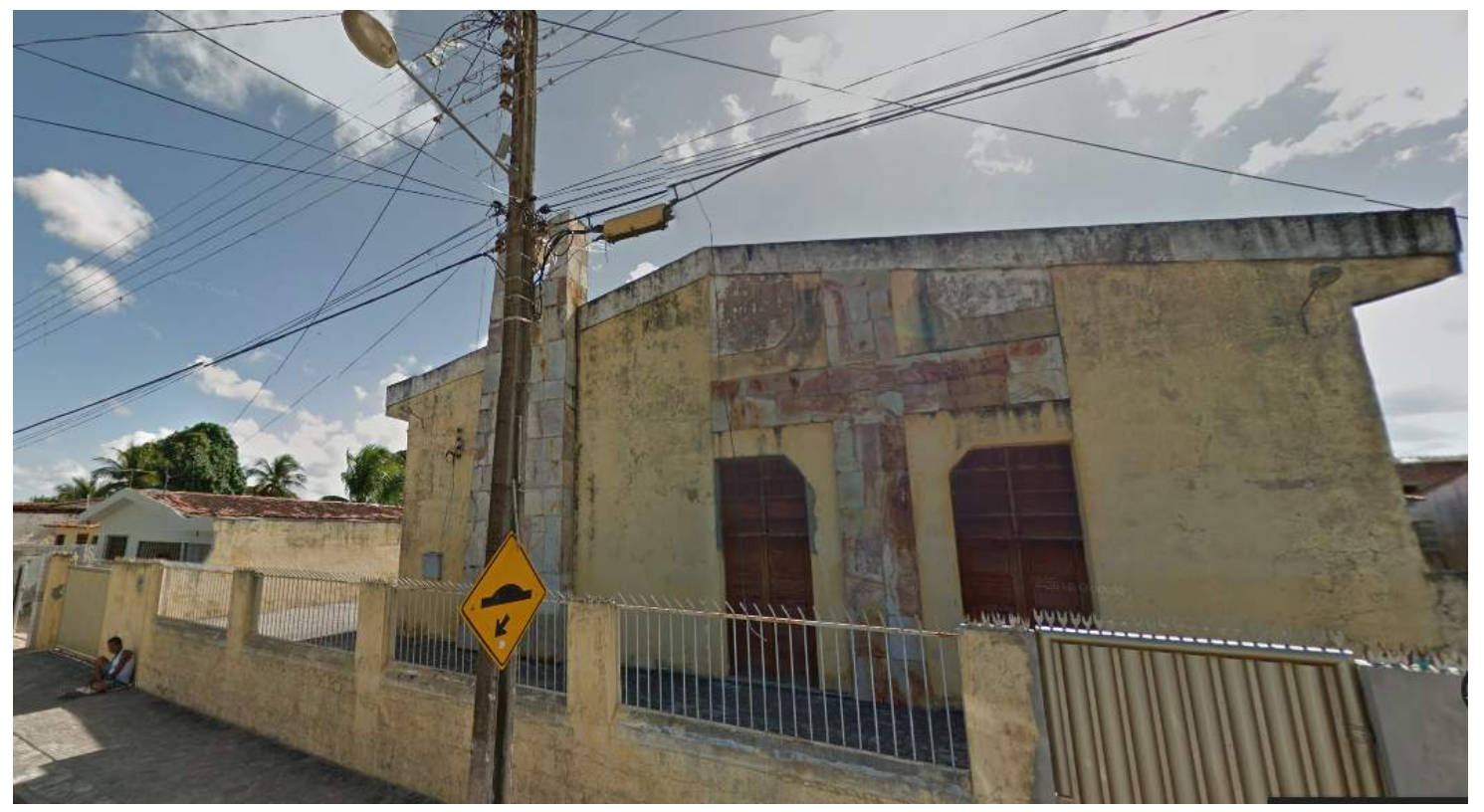

Foto 4. Visão frontal, desde a Rua Bom Jesus, da Igreja do Bom Jesus, próximo à casa de Carlos e Carlinhos. 


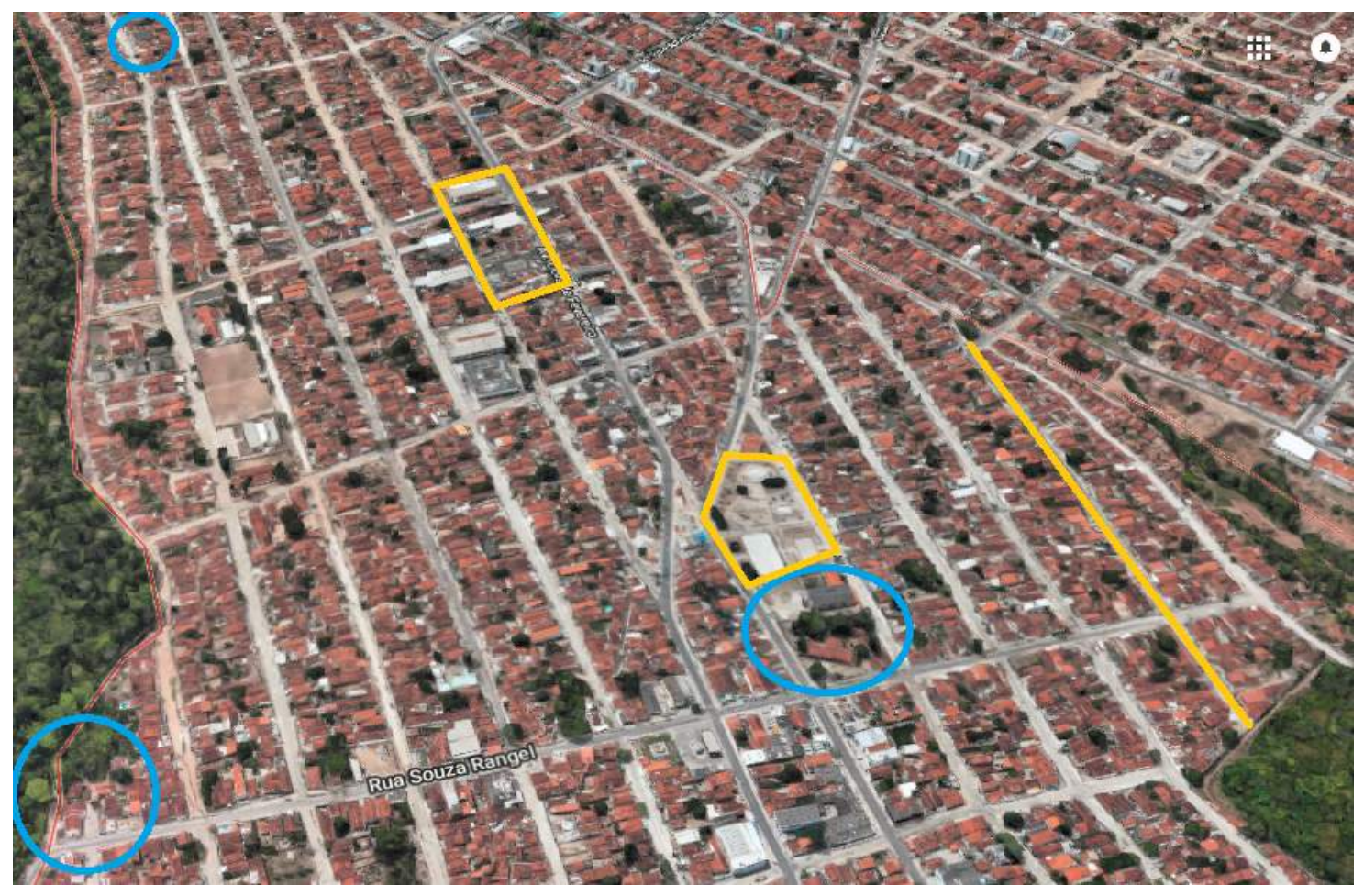

Foto 5. Visão aérea do lugar Rangel, na narrativa de Carlos e Carlinhos. O Rangel teria se iniciado na Igreja São Francisco de Assis, destacada em azul, e se espalhado para oeste, seguindo a Rua Souza Rangel. O segundo círculo em azul destaca a Igreja São Francisco de Chagas, cujo terreno se estende de norte a sul, fazendo fronteira com a Rua Souza Rangel e seguindo pela Av. 02 de Fevereiro. Ao sul da Igreja São Francisco de Chagas, destacado em amarelo, localiza-se atualmente a Praça da Amizade, onde no passado fora um areal. Mais ao sul o retângulo amarelo aponta a zona comercial mais pulsante do Varjão/Rangel. 0 Círculo em azul, no topo da foto, situa a Igreja Bom Jesus. A reta amarela informa a localização da Rua Napoleão Laureano, onde a família de Carlos primeiro se estabeleceu ao chegar ao Varjão/Rangel. 


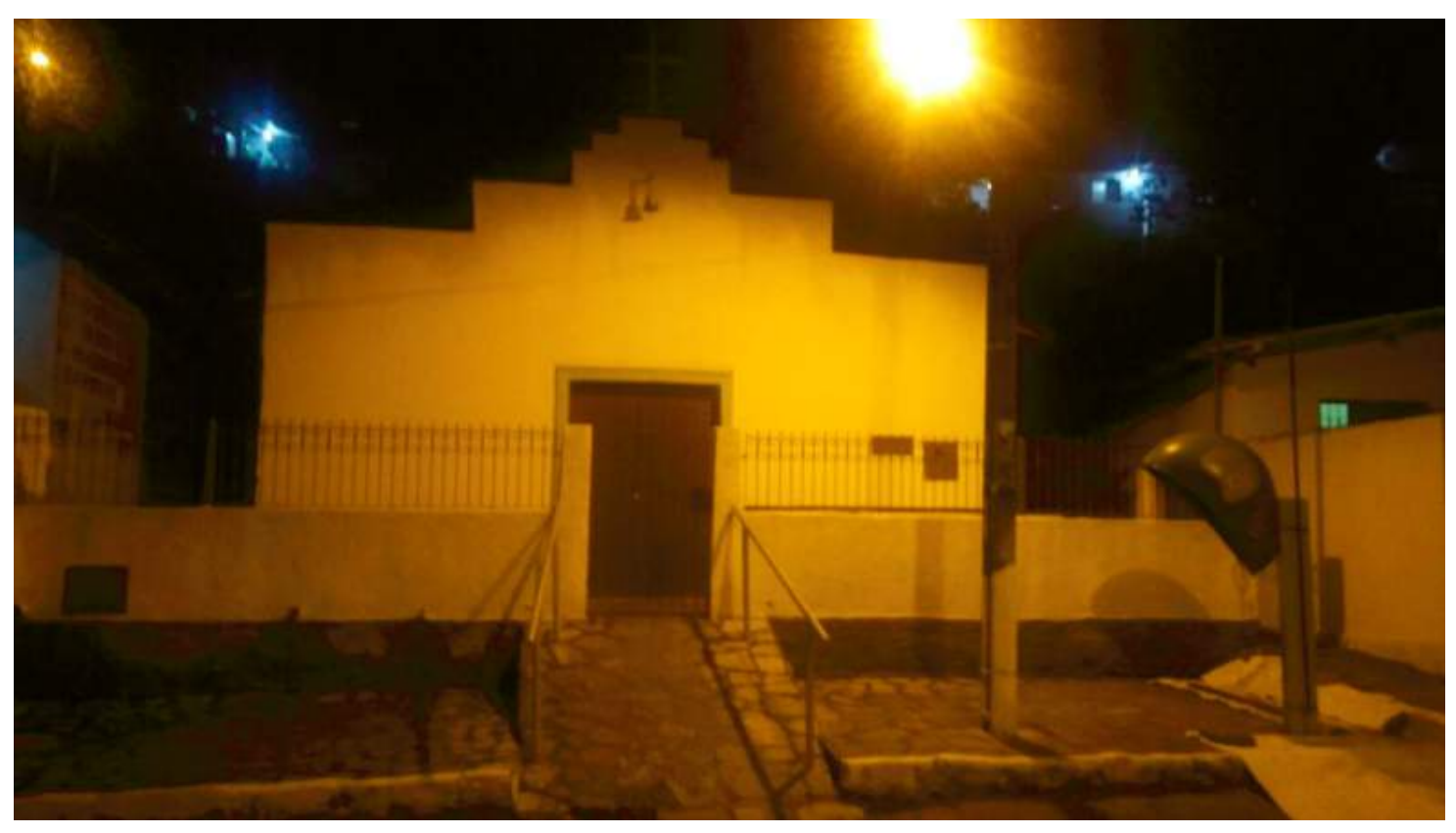

Foto 6. Visão frontal da Igreja Nossa das Graças, na Rua Oswaldo Lemos, fronteira norte do Varjão Rangel com o bairro de Jaguaribe. Os bairros são separados pelo Rio Jaguaribe.

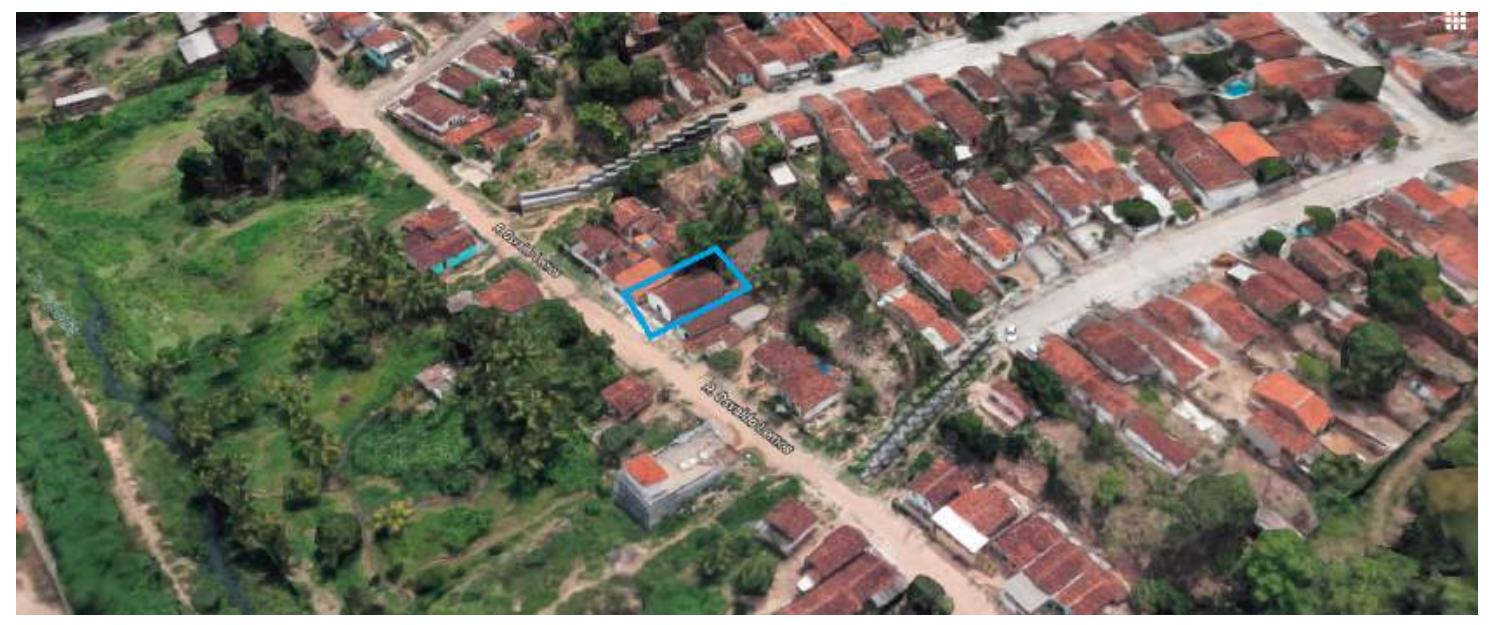

Foto 7. Visão aérea da Rua Oswaldo Lemos, com destaque para a Igreja Nossa Senhora das Graças, último ponto avançado no processo de colonização do Varjão/Rangel, na narrativa de Carlos e Carlinhos. 
o Varjão/Rangel as Ruas São Geraldo, Bom Jesus, São Judas Tadeu, Rangel Travassos, Quatorze de Julho, Dois de Fevereiro e Leonel Pinto de Abreu. O nome da Rua Rangel Travassos, de acordo com a narrativa de Carlos e de Carlinhos explorada a cima, seria uma homenagem à figura de Maria Rangel Travassos, figura conhecida e querida pelos moradores por mediar a ocupação dos terrenos da família Rangel.

A denominação Varjão, pelo que se fez possível abstrair com base nas observações e nas conversas informais com os moradores de todas as áreas do bairro, diz respeito, ainda, a uma paisagem por pacificar. Evoca, portanto, a imagem de uma sociabilidade caracterizada ora pela extrema pobreza, ora pela violência entre iguais.

A Foto 1, abaixo, mostra uma cena que tornou-se comum no Varjão/Rangel: a realização de pequenas obras de construção civil projetada e conduzida por famílias do próprio bairro para a acomodação das novas gerações e, também, para o desfrute de um padrão de vida de classe média baixa em vias de consolidação. Esta obra, batizada de Residencial Príncipe do Rangel, vem a ser emblemática, entre os mais de vinte canteiros de construção já contados ao longo do bairro, justamente pelo seu porte e arrojo, - indicando um avanço na integração moral e econômica do Varjão/Rangel na cidade de João Pessoa, - mas, sobretudo, pela ousadia simbólica em afirmar publicamente o nome e o lugar Rangel de forma tão oportuna: este residencial se situa na Avenida 02 de Fevereiro, o mais importante corredor viário do bairro, de frente para a Praça da Amizade, o maior espaço de lazer e de sociabilidade jovem à disposição do morador e, ainda, compreende uma barreia física visual para a Comunidade Paturi, cuja entrada se localizada por trás do Residencial Príncipe do Rangel.

O bairro do Varjão/Rangel, com efeito, apresenta um processo de sociabilidade marcado por uma intensa pessoalidade e forte copresença do morador na vida do outro, vizinho próximo e íntimo de longa data, muitas vezes para mais de uma geração. Esta característica do bairro se alia ao fato de ser este um lugar classificado como violento, de moralidade degradada, e, também, perigoso, onde se confrontam códigos de conduta e comportamento assentados em noções mais tradicionais de honra e dignidade, gratidão, confiança e reciprocidade com modos e estilos de vida mais individualistas. Este individualismo emergente é vivido pelo morador do bairro na enorme tensão entre o ajustar-se 


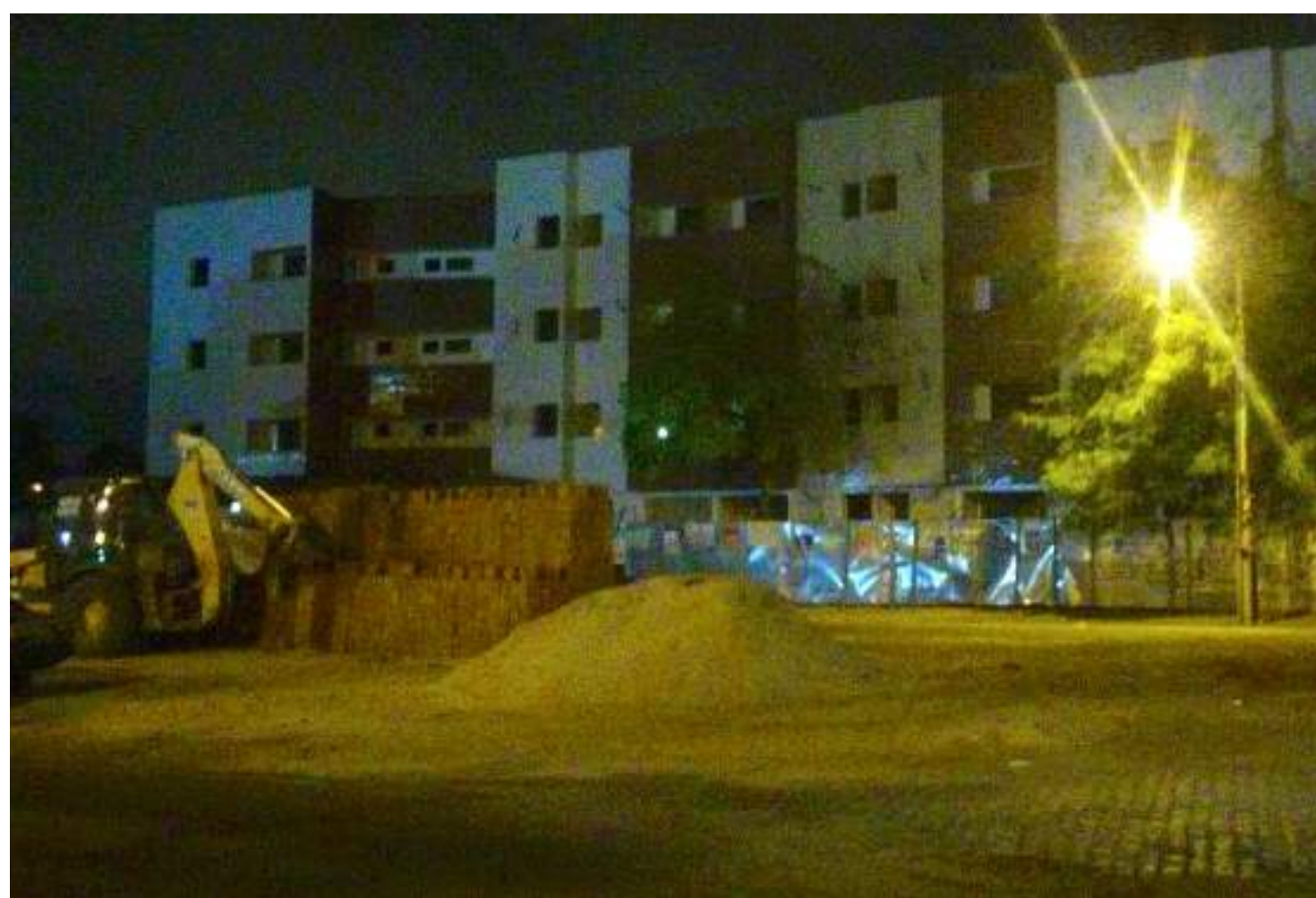

Foto 8. Visão, desde a Rua 02 de Fevereiro, da construção do Residencial Príncipe do Rangel

aos códigos modernizantes da cidade, que o acusa de forma generalizada de incivilizado e como elemento de perigo, e de buscar manter, ainda que de maneira constrangida e ressentida, os vínculos mais próximos e engolfados com o outro próximo na rua, na vizinhança e no bairro, correndo, para tanto, os riscos de ser associado à moralidade e ao lugar Varjão.

Nesse sentido, o morador do Varjão/Rangel lança mão de estratégias de evitação e segregação de platéias e informações, assumindo, para o olhar moralizante da cidade, o discurso de uma pretensa impessoalidade, nas suas relações, como desculpa de si. Em conversa com F. M. da Silva, senhora de 51 anos, moradora da Rua Abdias dos Santos Passos, por exemplo, o pesquisador pode registrar o esforço do morador em dissociar-se de qualquer contato com o lugar Varjão, descrito, nas entrelinhas, como contexto de fofocas, de pessoas desocupadas, mal educadas, que vivem nas portas do outro, e também de pequenos bandidos e drogados.

F. M. da Silva disse gostar do bairro, apesar de que 'o povo diz que é violento, mas nunca aconteceu nada'. Segundo ela, o Varjão/Rangel é um 'bairro bom'. Ela conhecia pouca gente, ali, porque tinha uma ro- 
tina de trabalho bastante intensa: saia de manhã e chegava somente à noite. Para ela, os principais problemas do bairro eram a 'segurança pouca', a 'falta de água demais' e a 'Saúde péssima', enquanto que, por outro lado, o bairro oferecia boas feiras e estava bem localizado. A moradora se encontrava na calçada de sua residência, fumando um cigarro, quando foi abordada para uma breve conversa. Era por volta das 9h, mas já fazia bastante calor. Ela convidou o pesquisador para entrar para o terraço da casa e buscou uma cadeira. Tratava-se de uma residência simples, por fora, toda envolvida por um muro alto que escondia totalmente a casa. Por dentro, porém, percebia-se o quanto se investia no local, ainda em reformas, mas já bastante organizado e limpo. F. M. da Silva informou que tinha estudado até a quarta série do primeiro grau e trabalhava como diarista fora do bairro. A renda mensal do seu domicílio era de $R \$ 900,00$. Ela era uma mulher solteira que frequentava a religião católica. Na casa, viviam ela e a filha: uma moça de seus vinte anos. Informou ainda que ela era natural do município de Santo André, mas que tinha se mudado para João Pessoa já há 42 anos, já, quando tinha apenas 9 anos de idade. Ela revelou ter vindo sozinha para trabalhar em casa de uma família como doméstica. Esta família era o seu único contato, de modo que foi morar no bairro da Torre, onde a família empregadora residia. Depois disso teria morado, ainda, no bairro de Manaíra e, por fim, no bairro do Varjão/Rangel, onde se fixara há 16 anos. Já há 16 anos naquela rua, F. M. da Silva disse gostar da mesma, que era boa. Os problemas maiores eram a falta de educação do povo, que tinha que aprender a ser mais educado. Segundo ela, havia 'muita mundiça na rua'. O melhor da rua eram o calçamento, a iluminação boa e os vizinhos ótimos. Neste ponto, porém, ela insistiu que não ficava nas portas dos vizinhos. A entrevistada disse não possuir amigos na rua. A conversa foi interrompida bruscamente, nesta altura, porque o vizinho se postou praticamente em cima do muro e iniciou uma conversa com F. M. da Silva. Se dirigindo ao pesquisador, com um sorriso, ela disse que aquele senhor que se amostrava, o Fabinho, era seu único amigo. Acrescentou, então, que não tinha tempo e que não vivia nas portas. $\mathrm{Na}$ verdade, preferia viver sozinha. Em relação ao Varjão/Rangel, sempre denominado de Rangel e jamais de Varjão, F. M. da Silva afirmou não possuir amigos, uma vez que a falta de tempo impedia uma vida social mais intensa no bairro. As suas amizades estavam no local de trabalho. Quanto à vizinhança, da qual gostava, ela disse que as pessoas eram boas, prestativas e se ajudavam mutuamente. Ela revelou que ajudava e buscava ajuda em casos de dificuldade. Neste sentido, enfatizou que estava sempre pronta a ajudar os vizinhos com as atividades do dia-a-dia e em caso de problemas de Saúde. Além disso, ela contribuía financeiramente com uma ONG contra o câncer. Sua rede de solidariedade, com a qual ele contava para as atividades do dia-a-dia, em casos de problemas de Saúde, e de necessidade de apoio emocional e afetivo e de apoio financeiro, se espalhava principalmente pelo bairro do Varjão/Rangel e por outros bairros. As formas mais usuais de ajuda eram o apoio emocional e afetivo e o apoio financeiro. Ao falar brevemente sobre a sua pessoa, F. M. da Silva disse não poder reclamar da vida, pois que era uma pessoa que tinha saúde e 'coragem de trabalhar', que não criava confusão e que tinha seu canto e sua família. Em síntese, ela afirmou ser uma pessoa feliz. Em relação aos seus projetos e planos pessoais, almejava terminar de construir sua casa e, então, comprar uma casa para a filha. Este era, também, o plano ou projeto que tinha para a família. A noção de segurança, para Francisca, estava fortemente centrada na ideia de possuir uma casa: seu canto, como afirmou. Em relação aos medos que 
sentia por morar no Varjão/Rangel, aludiu somente à figura do ladrão Ihe inspirava esta emoção tão desconfortante. Ela contou que tinha bastante medo do que um ladrão era capaz de fazer, algo que era reforçado por traumas recentes porque havia passado: tinha sofrido duas tentativas de assalto, no bairro, ultimamente. Ela informou, neste sentido, que o Varjão/Rangel estava cheio de 'cheira cola' e de drogados, o que lhe era capaz de causar uma 'tremedeira que não para'.

O discurso do morador, nesse sentido, oscila rapidamente entre o amor e o ódio à sociabilidade engolfada, extremamente absorvente moral e emocionalmente, do bairro. Percebe-se, na narrativa sobre o cotidiano de vivências das tramas relacionais, um ressentimento latente pelo estigma imposto pela cidade de João Pessoa ao Varjão/Rangel, expresso na ambiguidade de uma pertença envergonhada a uma cultura emotiva que acolhe calorosamente com gestos de solidariedade, reciprocidade, intimidade e reconhecimento, mas que também potencialmente suja e ameaça a fachada individual de cada morador com os elementos de pobreza e de incivilidade que pesam sobre o bairro.

Estes elementos problemáticos e sensíveis da identidade local comporiam, assim, um cenário urbano degradado, perpassado por tensões e por medos e que se reconhece a partir do estigma que envergonha seus moradores em relação à cidade de João Pessoa. O Rangel, por outro lado, é associado a um bairro tranquilo, e se apresenta como sociabilidade que se quer mais urbana, mais moderna, e integrada no centro da cidade, próximo ao bairro de classe média do Cristo Redentor, com seu comércio pulsante que orgulha os moradores, muito embora os vários problemas que o bairro apresenta gerem uma dinâmica de interconhecimento que dificulta a construção e a manutenção de ações egocêntricas de territorialidade dissociadas dos estigmas que pesam sobre o lugar e sobre aqueles que o movimentam.

Muitos moradores do Varjão/Rangel, portanto, demonstram uma ambiguidade latente, quando informam seu sentimento de pertença ao bairro, uma vez que se percebem tolhidos em seus espaços privados e íntimos para o desenvolvimento de uma personalidade individual mias autônoma para além das tramas relacionais e dos compromissos morais locais. A ambiguidade se encontra, nesse sentido, situada entre o orgulho de pertencer a uma instância de solidariedade, proximidade e, sobretudo, semelhança de destinos e projetos, quando, ao mesmo tempo, este engolfamento relacional (SCHEFF, 1990) provoca também um intenso constrangimento pela intensidade do interconheci- 
mento que promove uma vigilância contínua de um morador sobre o outro, como, por exemplo, através da fofoca (KOURY \& BARBOSA, 2017) e da atualização de códigos familísticos e vicinais de honra e critérios de prestígio (PRADO, 1998).

A figura do bandido e o discurso da violência emitido pela mídia e pela cidade são, assim, amplamente explorados pelos moradores como elemento definidor da sociabilidade Varjão e não do bairro Rangel. Os moradores, assim, afirmam tratar-se de um problema que o outro do e no bairro, no caso o morador do Varjão, teima em trazer para o Rangel, contaminando e sujando, desta forma, a imagem do bairro Rangel como lugar de pessoas de bem, decentes e trabalhadoras. O que reforça a identidade dupla, dúbia e ambivalente dos moradores, traduzida em desculpas e acusações de dois bairros em um só território como estratégia de salvaguardar a própria face e a reputação do bairro a que afirmam pertencer: o Rangel.

O olhar estigmatizado e ressentido do morador ao assumir o discurso da cidade sobre si e sobre o outro morador como potencialmente perigoso o faz, de um lado, rejeitar o estigma para si, mas, por outro lado, o faz também acusar o outro do bairro como aquele possível elemento de perigo que o discurso da cidade emite. Este movimento de aproximação e distanciamento, de semelhança e dessemelhança para com o outro, no ser-lhe solidário, mas também de negá-lo oportunamente, como forma de protegerse de uma associação de si com a identidade estigmatizada do bairro, aliado a uma situação de intensa pessoalidade, gera entre os moradores uma dinâmica de insultos morais e ressentimentos. Insultos morais e ressentimentos estes bastante sutis, quase que invisíveis se tomados isoladamente, mas que se acumulam cotidianamente e se expressam na forma de medos corriqueiros e de vergonha cotidiana. No Varjão/Rangel esse outro estigmatizado, perigoso, sujo e violento se encontra, no discurso do morador, na dicotomia esquizofrênica de um Varjão, diferente de um bairro em que se quer viver, o Rangel.

As disputas morais cotidianas recorrentes entre os moradores do Varjão/Rangel em torno desta identidade ambígua e ambivalente, dupla e dúbia, oficial e oficiosa do bairro, como espaço societal de medos e estranhamentos e estigmatizado pelos próprios moradores e pela cidade de João Pessoa, aponta para os elementos emocionais 
e morais corriqueiros presentes na sociabilidade do bairro, como a pobreza absoluta em algumas áreas fronteiriças do Varjão/Rangel; a busca do morador pela prestação de serviços públicos essenciais no bairro, na rua e nas próprias casas; a desconfiança do morador em relação às autoridades públicas, que aparecem como um poder impessoal e injusto ao não compreender a dimensão moral do cotidiano da vida do personagem anônimo em suas redes de interdependência bastante tensas e ambíguas; o papel da fofoca na construção de redes de intriga e de desfiguração e estigmatização do outro de quem se quer vingar ou tirar proveito; os pequenos gestos de solidariedade e ajuda mútua; a negociação cotidiana na conformação de vínculos sociais tidos como imorais, mas que se tornam importantes no processo de organização e de sentido da vida e da experiência cotidiana, nas situações abarcadas por contextos simbólicos específicos. Estes elementos todos, uma vez observados e registrados, possibilitam uma reflexão mais aprofundada sobre os sentidos dos códigos de moralidade e da cultura emotiva entre os moradores do bairro.

O Varjão/Rangel, portanto, se apresenta como sociabilidade urbana moral e emocionalmente fraturada em sua identidade dupla e dúbia, a um só tempo Varjão e Rangel, mas sempre em reiterado esforço de depuração de uma forma de identificação em detrimento da outra, sem a qual não pode existir completa e satisfatoriamente (BARBOSA, 2015; KOURY, 2017). Varjão, Rangel, Varjão/Rangel não constituem, assim, nominações que representam complementaridades, acordos ou jogos de alianças entre possíveis leituras de passado e de projetos de futuro, mas como imagens de lugares sobrepostos em um mesmo território e que se chocam em disputas morais e identitárias inconclusas, oportunamente utilizadas pelo morador do bairro para se identificar e se desidentificar conforme seu enquadre ou definição da situação, isto é, de acordo com as exigências sociais, muitas vezes externas ao bairro, que recaiam sobre a sua fachada individual e coletiva.

As figurações sociais no bairro aparecem como ambíguas e ambivalentes, de modo que confiança e traição, amor e ódio perpassam as situações mais banais e corriqueiras dos moradores, engendrando, assim, regimes de justificação, redes de intriga e canais de fofoca densos e distribuídos de forma acêntrica no bairro, bem como uma dinâmica de desculpa e acusação de si e do outro que contamina todos os moradores como 
bons e maus, como habitantes do Varjão e do Rangel. A intensa pessoalidade, a copresença continuada e o estigma que pesa sobre as sociabilidades urbanas desta identidade dupla e dúbia, são elementos que potencializam as vulnerabilidades interacionais e as possibilidades de insulto moral, e mesmo de violência banal, entre os moradores.

Um registro no diário de campo de 30 de abril de 2017 resume bem este sentimento de desvalor e envergonhamento do morador local do bairro do Varjão/Rangel. Em um breve discurso proferido de improviso para uma multidão de jovens que acompanhavam o seu show, em frente ao CAC do Rangel, - uma casa de show bastante conhecida na cidade de João Pessoa por reunir jovens de baixo poder aquisitivo e supostamente baixo padrão moral, - e no domingo anterior ao feriado do Dia do Trabalhador, assim se expressou um dos artistas do bairro, visivelmente emocionado: "O Rangel é o bairro do carinho, do amor e do respeito... mas ninguém dá oportunidade".

As palavras de Carlinhos sintetizam bem a postura moral ambígua e ambivalente do morador do Varjão/Rangel em relação ao sentimento envergonhado de pertença pelo lugar estigmatizado, mas no qual se organiza a formação de um self também orgulhoso e esperançoso de que os processos de apropriação moral e emocional do bairro pela cidade de João Pessoa conduzam a uma urbanização que ofereça espaço às novas gerações e às antigas formas de identificação com o local: "O umbigo do meu pai ainda hoje está enterrado na Rua Napoleão Laureano, na casa onde ele nasceu. Eu tenho paixão pelo Rangel. Como eu te falei, a gente quer ficar e morrer aqui, e quem sai quer voltar".

\section{Considerações Finais}

O presente artigo buscou apresentar o lugar Varjão/Rangel como contexto interacional caracterizado por uma cultura emotiva e por códigos de moralidade próprios, mas sempre em relação dialética e tensa com o olhar moralizante e com as investidas de empreendimentos morais e cruzadas simbólicas da cidade de João Pessoa sobre o bairro. Bairro este de que a cidade busca apropriar-se moral e emocionalmente para o controle disciplinar da pobreza urbana e para o aproveitamento de recursos estratégicos, como, atualmente, as oportunidade de conexão viária ligeira do Centro da cidade com a sua zona sul emergente e pulsante, atravessando o Varjão/Rangel de norte a sul. 
O artigo aborda criticamente, assim, os códigos urbanos de pertença aos diversos lugares e regiões morais da cidade, bem como os processos interacionais de construção de sentimentos de confiança e confiabilidade com o outro generalizado (MEAD, 1973). Processos interacionais estes que atravessam, desde os anos de 1970, uma intensa reconfiguração no sentido do isolamento social do indivíduo em hábitos e espacialidades privadas, na perda das tradições da vizinhança e do bairro e na generalização de narrativas de violência, medo e insegurança. Esta reconfiguração moral-emocional e cognitivo-comportamental do cotidiano da cidade se apóia e se reflete fortemente nas estatísticas policiais de violência e de criminalidade e na arquitetura da violência que se estabelece como um lugar comum em praticamente todos os bairros da cidade a partir da segunda década do século XXI, compondo uma cultura generalizada do medo e da violência banal.

Nesse sentido, o Varjão/Rangel é discutido como lugar de projetos individuais e coletivos, de memórias ressentidas, de narrativas míticas e de discursos de evitação e de desculpa de si como Rangel e de acusação do outro como Varjão. Trata-se, com efeito de um discurso de ressentimento do morador do bairro em face do estigma que a cidade de João Pessoa projeta no bairro, classificado generalizadamente como sujo e perigoso, de degradação moral e de violência gratuita. Nesse contexto emerge o sentimento de amor e ódio, de pertença envergonhada e de orgulho pelo lugar Varjão/Rangel.

\section{Referências}

BARBOSA, Raoni Borges. Medos Corriqueiros e Vergonha Cotidiana: Um Estudo em Antropologia das Emoções. Cadernos do GREM № 8. Editora Bagaço: Recife; Edições do GREM: João Pessoa, 2015.

BARRETO, Cristina. Imagens da Cidade: A idéia de progresso nas fotografias da $\mathrm{Ci}$ dade da Parahyba (1870-1930). Dissertação. João Pessoa: Mestrado em Ciências Sociais/UFPB, 1996.

BECKER, Howard S. Outsiders: estudos de sociologia do desvio. Rio de Janeiro: Jorge Zahar, 2008.

DOMINGUES, José Maurício. A dialética da modernização conservadora e a nova história do Brasil. Dados, v. 45, n. 3, 2002.

DOUGLAS, Mary. Pureza e Perigo: Ensaio sobre a noção de poluição e tabu. Lisboa: Editora 70, 1991. 
DURKHEIM, Émile D. As Formas Elementares da Vida Religiosa. São Paulo: Martins Fontes, 2003.

ELIAS, Norbert. O Processo Civilizador, v. 2. Rio de Janeiro: Zahar, 1993.

, Norbert. A sociedade dos indivíduos, Rio de Janeiro: Jorge Zahar, 1994.

, Norbert. O Processo Civilizador, v. 1. Rio de Janeiro: Zahar, 2011.

GOFFMAN, Erving. Comportamento em lugares públicos: Notas sobre a organização social dos ajuntamentos. Petrópolis: Vozes, 2010.

, Erving. Os quadros da experiência social: Uma perspectiva de análise. Petrópolis: Vozes, 2012.

GUSFIELD, Joseph R. Symbolic crusade: Status Politics and the American Temperance Movement. Chicago: University of Illnois Press, 1986.

KOURY, Mauro Guilherme Pinheiro. Trabalho e disciplina (Os homens pobres nas cidades do Nordeste: 1889-1920). In: Francisco Foot Hardman et al. Relações de Trabalho \& Relações de Poder, Mudanças e Permanências. Fortaleza-Ce: Editora da UFC, p. 134-149, 1986.

, Mauro Guilherme Pinheiro. Sofrimento Social: Movimentos Sociais na Paraíba através da Imprensa, 1964 a 1980. João Pessoa: Editora Universitária UFPB, 2007.

, Mauro Guilherme Pinheiro. De que João Pessoa tem Medo? Uma abordagem em Antropologia das emoções. João Pessoa: EdUFPB, 2008.

, Mauro Guilherme Pinheiro. Etnografias Urbanas sobre Pertença e Medos na Cidade. Cadernos do GREM N 11. João Pessoa: Edições do GREM; Recife: Bagaço, 2017.

Mauro Guilherme Pinheiro e BARBOSA, Raoni Borges. Dissenso e fragmentação dos códigos pessoalizados de aliança: Fofocas, bochichos e outras formas cotidianas de controle e administração de tensões em um bairro popular. RBSE - Revista Brasileira de Sociologia da Emoção, v. 15, n. 45, 2016, p. 21-38.

MAYOL, Pierre. Bairro. In: CERTEAU, Michael de. et al. A invenção do cotidiano: 2. Morar, cozinhar. Petrópolis: Vozes, 2008, pp. 37-45.

MATTOS, Romulo Costa. As "Classes Perigosas" Habitam as Favelas: um Passeio pela Crônica Policial no Período das Reformas Urbanas. Desigualdade \& Diversidade: Revista de Ciências Sociais da PUC - Rio, v.5, n.2, 2009, p. 149-170.

MOORE, Barrington. Social Origins of Dictatorship and Democracy: Lord and Peasant in the Making of the Modern World. Boston, MA: Beacon Press, 1966.

Brasiliense, 1987.

Barrington. Injustiça: as bases sociais da obediência e da revolta. São Paulo:

PARK, Robert et al. The city. Chicago: University of Chicago Press, 1925.

REZENDE, Cláudia Barcellos; COELHO, Maria Cláudia. Antropologia das Emoções. Rio de Janeiro: Editora FGV, 2010.

PRADO, Rosane M. Cidade pequena: Paraíso e inferno da pessoalidade. Cadernos de 
Antropologia e Imagem, n. 4, pp. 31-56, 1998.

SCHEFF, Thomas J. Microsociology: discurse, emotion and social structure. Chicago: University of Chicago Press, 1990.

, Thomas J. A vergonha como a emoção principal da análise sociológica. Alguns exemplos nas músicas populares. RBSE - Revista Brasileira de Sociologia da Emoção, v. 10, n. 28, pp. 74-86, 2011.

TRAJANO FILHO, Wilson. Território e idade: ancoradouros do pertencimento nas manjuandadis da Guiné-Bissau. In: Wilson Trajano Filho. Lugares, pessoas e grupos: as lógicas do pertencimento em perspectiva internacional. Brasília: ABA Publicações / Ed. Athalaia, p. 227-257, 2012. 